\title{
The Impact of Policy Announcement on Stock Market Volatility: Evidence from Currency Demonetisation in India
}

\author{
Dr. S. Sathyanarayana ${ }^{1}$, Prof. Sudhindra Gargesha ${ }^{2}$, \\ ${ }^{1}$ Associate Professor, MP Birla Institute of Management, Bangalore \\ ${ }^{2}$ Joint director, MP Birla Institute of Management,
}

\begin{abstract}
The aim of the current empirical paper is to investigate the impact of major political events and its impact on stock market with special reference to BSE Sensex, Nifty fifty and BSE100 index. History has exhibited that stock market plays a major role in any economy. Stock markets have been impacted by various macro and micro economic factors. Therefore, the main objective of this empirical paper is to investigate the pricing behaviour of the chosen benchmark indices (Sensex, Nifty and BSE100) with respect to a major political event in India (demonetisation of currency) and its implications on regulators, researchers and market participants. For the purpose of the study the data has been collected from 26-10-2015 to 30-11-2016. The collected data has been tested for stationarity by applying ADF test statistics. The event study methodology has been employed to determine the impact of demonetisation on India bench mark indices. In order to capture the historical volatility the standard deviation of the abnormal returns of the selected indices has been computed. GARCH $(1,1)$ model has been employed to ascertain the existence of ARCH/GARCH effect in the indices. We found a significant impact of currency demonetisation on the chosen indices on the event day. Nobody knows the actual impact of demonetisation on the economy in the long run. Bulk of the studies and opinions of experts on the demonetisation is mixed. Some experts opine that the impact on the economy would be significant and adverse. However, another bunch of experts opine that the shock on the economy would be smaller, although no extensive macroeconomic assessment has been published.
\end{abstract}

Keywords: Demonetisation, EMH, GARCH (1,1), ADF test, Event study, Abnormal returns.

\section{Introduction}

The Efficient Market Hypothesis popularly known as EMH claims that in informationally-efficient markets, stock prices fully reflect all the relevant information that is available in the market about a stock. The concept of efficient market was proposed by Eugene Fama (1970). According to him the prices of securities reflect on all the available macro and micro economic information. If the stock market is efficient then stock prices adjust immediately to the new information. The major implication of this theory is that new data regularly enters the financial market in the form of stock split, mergers and acquisition, issue of bonus shares, earnings announcement, and political issues. If the market is efficient then security prices adjust to new information. This means that the security prices reflect fully all the information that is available in the market, and stock returns follow a random walk, unpredictable, without pattern, and it is practically impossible for a trader to predict stock prices in order to "beat the market". The EMH concept has been studied since its inception by both practioners and academicians. The concept of event study methodology was first pioneered by James Dolley (1933), who used this method to investigate the returns pattern on stock split announcement. Later, Archie Bakay (1948) and John Ashley (1962) used this event study methodology. Today, the event study methodology is one of the most applied analytical tool in financial literature and has emerged as a very important statistical technique for analysing the impact of corporate actions such as stock split, earnings announcement, bonus shares etc. and major economic events such as budget proposal, general elections, oil shocks, terrorist attack, etc. on the security prices.

The notion of Efficient Market Hypothesis has been explored on numerous occasions over the years for various economic and dramatic events like general elections (James Ndungu Kabiru et al. (2015), Ling-Chun Hung (2011), Maning (1989), Roberts (1990), Gemmil (1992), Ling-Fang Liu (2007), Ray M. et al. (2009), Wing-Keung Wong and Michael McAleer (2007), (Jones 2008), Leblang and Mukkherjee (2005), Guo (2003), Booth and Booth (2003), Hensel and Ziemba (1995), Kumar Deva et al. (2015), Herron et al. (1999), Bechtel and Füss (2010)). Cutler, Poterba and Summers (1989) in their study argued that returns on the special event days are more volatile than returns on the non-event days. Couple of studies tried to explore the impact of political instability on the stock market for example Arzu (2011), (Chan \& John Wei, 1996), (Suleman, 2012). Some empirical studies tried to investigate the unfavourable political news and its impact on stock markets for example, Schwert (1989), Kongprajya, 2010, Mei \& Guo, 2002 \& Lin \& Wang, 2005, Nishat, M. and Mustafa, K.; 2002 and Swary (1986). These studies concluded that the favourable political news have a positive impact on stock market. However, unfavourable political news have a negative impact on stock returns and creates 
turmoil in stock market Lin and Wang, (2005) Clark, Masood and Tunaru, 2008, Salameh \& AlBash (2011). Studies conducted by Diamonte et al. (1996), Erb et al. (1996) demonstrated that the impact of political risk is greater in the emerging markets than in developed markets. However, Frey and Kucher (2000), Mansfield \& Pollins (2003) and Rigobon and Sack (2005) tried to investigate the impact of wars on the stock market and they found significant evidence. Handful of studies to tried to explore the impact of terrorist attack and stock market (Aslam and Kong (2011); Suleman (2012); Akysha and Shakil (2005)) including September 9/11 attacks (Carter and Simkins (2004)). Alesina and Sachs (1986) tried to investigate the possibility of re-election and its impact on stock market. Special events like Tiananmen Accident on stock market (Ma, Sun and Tang (2003)), resignation of a president (Ahmad (2009)), the crash of the space shuttle Challenger (Maloney and Mulherein (2003)) and the impact of hurricane on stock market (Angbazo (1996)) have been investigated by the researhers. Few empirical studies tried to investigate the impact of Union budget on stock market for example, Gupta and Kundu (2006); Kaur (2004), Divya et al. (2015); Rao (1997); Thomas and Shah (2002); Kutchu (2012); Babu and Venkateswara (2013); Soni Anil (2009). Majority of these studies documented that most of the political events such as general elections, policy announcements, favourable political news, terror attacks, re-elections, political instability have a greater influence on stock movements. Moreover, the stock markets are highly sensitive to both national and international events and react spontaneously after their occurrence. Volatility in security prices during such political events is an opportunity for testing the validity of the efficient market hypothesis. Abrupt political events like Greece crisis, Breixt referendum and currency demonetisation can put more pressure on the stock market and the way it functions. Therefore, the current study has been undertaken to investigate the impact of currency demonetisation and its impact on the bench mark indices of the Indian stock market.

In the current empirical study we have taken an important event after the Brexit 2016, which shook the Indian financial markets. The central government decision of demonetisation of Rs. 500 and Rs. 1,000 currency notes was a policy enacted on $8^{\text {th }}$ November 2016, ceasing the usage of all Rs. 500 and Rs. 1,000 currency notes as legal tender in India after $9^{\text {th }}$ November 2016. The major objective behind demonetisation of higher denomination currency is to curb financing of terrorism through the fake currency notes and use of such proceeds to finance prohibited activities such as smuggling of arms, terrorist activities etc. into India. The second objective behind demonetisation of currency is elimination of unaccounted money which was working like a parallel economy. According to Harish Damodaran (2016) as per the RBI the total bank notes in circulation valued to Rs.16.42 trillion (US\$240 billion) of which nearly 86\% (around Rs.14.18 trillion (US\$210 billion)) were Rs.500 and Rs.1,000 banknotes. In terms of volume, the report stated that 24\% (around 22.03 billion) of the total 90266 million banknotes were in circulation. However, the scrapping of higher denomination currency has created a shortage of cash in the system, leading to a lot of hardship for the general public and businesses. Since the Indian economy is more dependent on cash, as only less one third of the people uses banking system for transactions, demonetisation has hit business and consumption very hard. Consequent to this decision, on $9^{\text {th }}$ November 2016 , the Sensex plunged by 1,688 points $(6.12 \%)$ and the Nifty Fifty dropped 541.30 points $(6.33 \%)$. The rupee was trading to 66.85 per US $\$$ down by 23 paise. There are great levels of uncertainty about the consequences of demonetisation that is what would happen to the economy at large. Moreover, the market participants and regulators expect markets to react to such policy announcements. Yet, they may lack the competency to measure properly the vigour and the direction of the reaction. Therefore, the demonetisation decision would have a very robust economic implication for market participants. A stock market's sharpness to incorporate state-of-the-art information into prices is often referred to informational efficiency. Therefore, an impartial stock market is one in which security prices unbiased estimation of fundamental values of financial assets. Now a days, the legitimacy of market efficiency is challenged by the behavioural finance literature. Therefore, the main aim of this research paper is to investigate the pricing behaviour of the chosen Indian stock Indices (Sensex, Nifty Fifty and BSE100) with reference to a major policy announcement and its implications for regulators, researchers and market participants.

\section{Literature Review}

The random-walk theory assumes that security price is not correlated with historical prices. It assumes that there is no trend is visible in stock price movements and they are independent. Therefore, the Efficient Market Hypothesis theory suggests that historical prices have no predictive capacity over the future prices. Thus, subsequent price shift should be random (Alexander (1961); Ball and Brown (1968), Fama, (1965); Rosenstein and Wyatt (1990), Chopra et al. (1992), Malkiel (1995), Jensen and Benington, (1970), Fama, (1970), DeBondt and Thaler (1985), Kothari and Warner (1997), Elton et al. (1993), Collins and Dent (1984), Seppi (1992); MacKinlay (1997), Campbell, Lo, and MacKinlay (1997), Corrado (1989), Jensen and Ruback (1983), Charest (1978) and Jarrell, Brickley and Netter (1988)). The event study methodology is one of the most used tool in economics, accounting and financial research. The first event study documented in the financial literature was by James Dolley (1933), cited in MacKinley (1997) in his article Event Studies in 
Economics and Finance. John Dolley tried to explore how share prices react to stock splits announcement and found that there was an impact to the extent of 60 percent. Later many researchers have employed this methodology for example John H. Myers and Archie Bakay (1948), John Ashley (1962); Subramani. M. \& E. Walden (2001), Cannella and Hambrick, (1993), MacKinlay (1997); Chaney et al. (1991), Kothari and Warner (2006), Morck and Yeung, (1992), DeFond et al.(2010), Jeong and Lu (2008), Das, Sen and Sengupta (1998). But, what event study methodology are we following today was outlined by Ball \& Brown (1968) and Fama et al. (1969). In simple words, event study methodology examines the behaviour of corporates' stock and bond prices (returns) around specific events.

Stock market attitude during general elections was examined by researchers, for example Bialkowski et al. (2008); Zach (2003); Ray M. \& Nickles (2009), Nicholas Chen (2004); Pantzalis et al. (2000); Huang (1985), Beaulieu et al. (2005); Liu (2007); Khalid, Ahmed et al. (2010); Gartner (1994); Gartner et al. (1995); Acemoglu, et al. (2003); Dopke and Pierdzioch (2006); Stovall (1992); Anoop Singh (2006); Kim and Mei (1999); Zach (2003), Gärtner and Wellershoff (1995), Leblang and Mukherjee (2005), Leduc \& Pammett (2013), Abidin \& Martin (2010). Beyer et al. (2008); Nordhaus, (1975); Li and Born (2006); MacRae, (1977); Ploeg (1984); Beaulieu et al. (2005), Bernanke and Kuttner (2005); Martínez and Santiso (2003), Cowart (1978), Hibbs (1977), Allvine, O’Neill (1980); Drazen (2001) and Sturm (2013); Johnson et al. (1999) and Zhao et al. (2004). However, Nordhaus (1975) created the first political business cycle. In this pioneering study he deliberated the various issues like the political decisions pertaining to the current or future welfare. Lamasigi (2002) explored the impact of presidential elections in Indonesia stock market and found a significant impact. Kim and Mei (1994) investigated the impact of political events and its impact on Hang Seng stock index and found a significant impact. In a study by Sathyanarayana and Garagesha (2016) with an objective of impact of Brexit referendum on the Indian stock markets found a significant impact of Brexit referendum on Nifty fifty and Sensex indices on the event day. Chauvet and Collier (2008) in their study concluded that the political party in power always lure the voters by offering benefits and election centric reforms in the preelection period to attract more votes. In an empirical study by Lim et al. (2008), documented that general elections and other important political events have a short-term impacts on stock markets. Sathyanarayana and Pushpa B. V. (2016) tried to investigate the impact of Brexit referendum on global stock markets found a significant impact only on European stock markets and not on Asian and American stock markets. Bailey and Chung (1995) tried to investigate the impact of exchange rate fluctuations and political risk on the risk premium on individual stocks and found evidence in favour of the study. Similar evidence was documented by Beaulieu et al. (2005), Khalid and Kawai (2003). Niederhoffer (1971) in his seminal on political event and its impact on stock market documented that Cuban crisis (1962), has the major impact on stock market prices. In a study by Ferrera (2008), carried out an empirical study in the US, UK, Japan and France stock markets found a significant evidence with political conflicts and stock returns. Similar findings were documented by Brooks et al., (2005) Moser and Rose (2013) tried to investigate the regional economic agreements between the nations and its impact on stock market. In his study he found a significant evidence.

In an empirical study by Bittlingmayer (1992) documented that political confusion or uncertainty affects the stock market. Similar view was held by Schwert (1989). In a study by Tzachi Zach (2003) documented that returns on the TASE following political actions are more intense than returns on days that do not follow political actions. In an empirical study Zach (2003) documented that the stock market is highly volatile on event day as compared to ordinary trading days in Tel Aviv Stock market. In an investigation by Goodell and Vähämaa (2013) documented that the US election process generates uncertainty in stock market, similar view was documented by Ortega and Tornero (2009). In an empirical study by Zuwena Zainabu (2014) with an intention to understand the effect of the general elections on the return of the stock market in Kenya concluded that investors should carefully plan and carry out investments during and after the periods of the general elections as the returns could be affected either positively or negatively during that period. In an empirical study by Diamonte et al. (1996) argued that political risk has a significant impact on developing economies than in developed economies. Similarly Erb et al. (1996) documented that country-risk measures have high degree of correlation with future equity returns. Peel and Pope (1993) explored the stock market's reaction during general elections and they find inefficiency in stock prices around the time of elections. Similar observation was documented by Campello (2007). A study by Booth and Booth (2003) documented that when the ruling party is republican the fixed securities had fetched significantly higher returns, however, under democrats the small cap stocks experiences the excess returns. Identical results were documented by Santa-Clara and Valkanov (2003); Huang (1985); Johnson et al. (1999); Pantzalis et al. (2000). However, couple of studies contradicted this view for example Jones and Banning (2000); Abidin et al. (2010) and Dopke and Pierdzoich (2006). In a study by Niederhoffer et al. (1970) concluded that the stock market performances during Republican and Democratic administrations have no systematic difference. Niederhoffer et al. (1971) empirically studied the reaction of the stock market on major world events and found an impact on the S\&P 500 index. Cutler et al. (1989) conducted identical studies by taking major world events and found a dissimilar 
returns and risk profile between the major events and non-events days. In a study by Evelita E. Celis and Leow Jia Shen (2015), found that the investors take asymmetric treatments to the election information and the government policy. In the twentieth century, intensive empirical studies of the events like terrorists attack and its impact on stock market became quite popular. For examples empirical studies done by Aslam and Kang (2013); Ramiah and Graham (2013); Marc Chesney et al (2011); Anh Phuong Nguyen and Carl E. Enomoto (2009); and Khakan Najaf et al. (2015) found the evidence. The issue of influence of currency demonetisation and its impact on the stock markets have not available in the literature, therefore the current study has been undertaken to investigate the impact of higher denomination currency demonetisation on Indian stock markets. The structure of the current research paper is as follows. Section two outlines the review of various empirical researches done in this field. However, section three discuss the sources of data and the research methodology employed for the purpose of the current study. In the penultimate section the results are presented and in the final section a brief discussion and conclusion have been drawn and the results are compared with the possible evidence.

\section{Data For The Purpose of the Study}

\section{Research Design}

As the current empirical study was analytical in nature, the data for the purpose of the study was dependent on secondary sources. For the purpose of the study BSE Sensex, Nifty Fifty and BSE100 indices were chosen. For study purpose, the adjusted closing price for the chosen indices namely Sensex, Nifty fifty and BSE100 have been collected from Capitalline data base. Daily returns are calculated as logarithmic differences of daily closing prices.

\section{Objectives of the Study}

The current has been undertaken with the following objectives.

1. To examine the reaction of Indian benchmark indices (Sensex, Nifty and BSE100) to currency demonetisation.

2. To examine whether there is any abnormal returns around the event date.

3. To investigate the Indian stock markets reaction reflect the market efficiency in semi strong form or not.

\section{Hypothesis of the Study}

H0: There is no significance difference between the mean returns before the event (currency demonetisation) and the after the (currency demonetisation) event. $\left(\mu_{1}=\mu_{2}\right)$

H1: There is a significance difference between the mean returns before the event (currency demonetisation) and the after the (currency demonetisation) event. $\left(\mu_{1} \neq \mu_{2}\right)$

\section{Plan of Analysis}

To investigate the impact of currency demonetisation on the Indian stock market (Sensex, Nifty and BSE100) the event study methodology has been employed. For the purpose of the study the data has been collected from 26-10-2015 to 30-11-2016 from capitalline data base. The first event study documented in the financial literature was by James Dolley (1933). Thereafter, Archie Bakay (1948), Masulis (1980), DeAngelo and Rice (1983) have utilised this methodology to investigate the impact of macro and micro economic variables on the stock markets. For the purpose of the study we have used the same methodology to investigate the impact of currency demonetisation on various selected stock indices. The dates on which the currency demonetisation came out were taken as the event date $(\mathrm{t}=0)$. The thirty one days enclosing the referendum (i.e., $\mathrm{t}=-15, \ldots \ldots, 0 \ldots,+15)$ is labelled as the event window. The days before the currency demonetisation event period (i.e., -245...-15) are labelled as the estimation period. The abnormal returns (AR) of the selected indices for the event window were computed. In order to get the flawless results log returns were computed on Sensex, Nifty Fifty and BSE100 indices for the entire study period.

In the first step the expected return for the window period (ER) was estimated by using the Sharpe's (1964) model $\left[\mathrm{R}_{\mathrm{it}}=\alpha+\left(\beta^{*} \mathrm{Rm}_{\mathrm{t}}+\mathrm{e}_{\mathrm{it}}\right)\right]$. In the second phase, the abnormal return (AR) was computed by deducting the Actual returns (AR) by expected returns (ER). In third step, the Cumulative Abnormal Returns (CAR) for the 30 days has been calculated. The CAR has been calculated by adding the daily AR for the entire event window of 30 days. It is generally applied to analyse the adjustment of prices to state-of-the-art information in our study it is the currency demonetisation. In the last phase student $\mathrm{t}$-test to test has been run to investigate the significance difference in the mean returns before and after the currency demonetisation. 


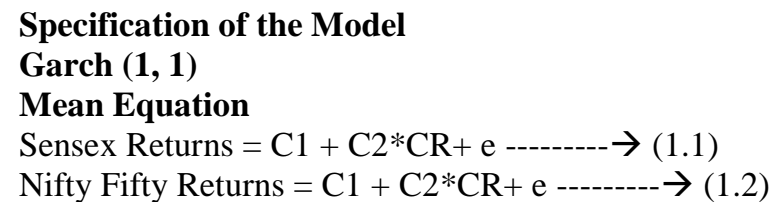

Sensex and Nifty Fifty returns - is the dependent variable and FTSE 100 is the independent variable

Variance Equation - This Is The Garch $(1,1)$ Model

$\mathrm{H}_{\mathrm{t}}=\mathrm{C} 3+\mathrm{C} 4 \mathrm{H}_{\mathrm{t}-1}+\mathrm{C} 5 * \mathrm{e}_{\mathrm{t}-1}^{2}+\mathrm{C} 6 * \mathrm{CR}------------\rightarrow(1.2)$

Here, $\mathrm{H}_{\mathrm{t}}=$ variance of the residual (error term) derived from equation 1.1 and 1.2 (current day's variance or volatility of Index return)

\section{Data Analysis}

In case of BSE Sensex, it was observed that the highest Abnormal Return (AR) recorded in the preevent period ranging from the lowest value of -0.0101515476237689 on day -5 with a $t$ value of -1.219944213 (statistically not significant) to the highest value of 0.005663454 with a t value of 0.680595559 (statistically not significant) on day -14. However, in the post-event period the highest Abnormal Return (AR) recorded ranging from the lowest value of -0.025237636 on day 2 with a $t$ value of -3 . -3.032888069 (statistically significant) to the highest value of 0.015938895 with a t value of 1.915428449 on day 12 (statistically not significant). On the event day (0) the abnormal returns were -0.016621546 with a t value of -1.997464731 (statistically significant). The Sensex results show that in -15 to +15 days event window period, none of the Abnormal Return (AR) were statistically significant at conventional level of $5 \%$ other than for day 2 (with an AR of $-0 .-0.025237636$ and $t$ stats of -3.032888069 ), day 4 (with an AR and t stats of -0.022265811 and -2.675754363 respectively), on day 8 (with an AR of -0.017735477 and $t$ stats of -2.131329493) and on the event day (0). Therefore, we can conclude that decision of demonetising the currency has an impact on BSE Sensex Index.

However, in case of Nifty fifty, it was observed that the highest Abnormal Return (AR) recorded in the pre-event period ranging from the lowest value of -0.010706433 on day -5 with a $t$ value of -1.281353132 (statistically not significant) to the highest value of 0.005031266 with a t value of 0.602145228 (statistically not significant) on day -14. However, in the post-event period the highest Abnormal Return (AR) recorded ranging from the lowest value of -0.026884853 on day 2 with a t value of -3.217597193 (statistically significant) to the highest value of 0.016848565 with a t value of 2.016447519 on day 12 (statistically significant). On the event day (0) the abnormal returns were -0.017557405 with a t value of -2.10128197 (statistically significant). The Nifty 50 results show that in -15 to +15 days event window period, none of the Abnormal Return (AR) were statistically significant at conventional level of 5\% other than for day 2 (with an AR of -0.026884853 an t stats of -3.217597193), day 4 (with an AR and t stats of -0.025936791 and -3.104132568 respectively), on day 8 ( with an AR of -0.021148345 and $t$ stats of -2.531048046), on day twelfth and on the event day (0). Therefore, we can conclude that decision of demonetising the currency has an impact on Nifty Index.

In case of BSE 100 it was observed that the highest Abnormal Return (AR) recorded in the pre-event period ranging from the lowest value of -0.0116064413685003 with a $t$ value of -1.382876007 (statistically not significant) on day -5 to the highest value of 0.004701071 with a $t$ value of 1.0 .5601 (statistically not significant) on day -14. However, in the post-event period the highest Abnormal Return (AR) recorded ranging from the lowest value of -0.029144016 on day 4 with a $t$ value of -3.472430 (statistically significant) to the highest value of 0.0 .0157436092148135 on day 12 with a t value of 1.8758083 (statistically not significant). On the event day the abnormal return was -0.018449605 with a t value of -2.1982203 (statistically significant). The Sensex results show that in -15 to +15 days event window period, none of the Abnormal Return0 (AR) were statistically significant at conventional level of $5 \%$ other than day the event day (0), $2^{\text {nd }}$ day (with an abnormal return of -0.02842942 with a t value of -3.387288313 ), on day 8 (with an AR of -0.022651876 with a t value of 2.698909621) and day 4. Therefore, we can conclude that the decision of demonetisation of Rs. 500 and Rs. 1000 currency notes have an impact on BSE 100 Index on the event day.

Table No. 4.1: T Test Results: Sensex

\begin{tabular}{|c|c|c|c|c|}
\hline & \multicolumn{2}{|c|}{ Sensex $* * 15$ days } & \multicolumn{2}{|c|}{ Sensex**7 days } \\
\hline & Variable 1 & Variable 2 & Variable 1 & Variable 2 \\
\hline Mean & -0.001150433 & -0.001949335 & -0.00641746 & -0.002189592 \\
\hline Variance & 0.000019371165 & 0.000141791 & 0.000158082 & 0.000018863399 \\
\hline t Stat & 0.243729224 & & -0.84091193 & \\
\hline \multirow[t]{3}{*}{ t Critical two-tail } & 2.10092204 & & 2.364624252 & \\
\hline & \multicolumn{2}{|c|}{ Nifty**15 days } & \multicolumn{2}{|c|}{ Nifty $* * 7$ days } \\
\hline & Variable 1 & Variable 2 & Variable 1 & Variable 2 \\
\hline Mean & -0.0022278346 & -0.001185326 & -0.00321332 & -0.002877759 \\
\hline Variance & 0.0 .00005460 & 0.000052549 & 0.00009469 & 0.000078715 \\
\hline
\end{tabular}


The Impact of Political Events on Stock Market Volatility: Evidence from Currency Demonetisation ..

\begin{tabular}{|c|c|c|c|c|}
\hline t Stat & -0.288521549 & & -0.84090103 & \\
\hline t Critical two-tail & 2.109815578 & & 2.364624252 & \\
\hline & \multicolumn{2}{|l|}{ BSE 100** 15 days } & \multicolumn{2}{|l|}{ BSE 100** 7 days } \\
\hline Mean & -0.001433021 & -0.00213224 & -0.00263440 & -0.006980377 \\
\hline Variance & 0.000021402704 & 0.000200562 & 0.0000278909 & 0.000246599 \\
\hline t Stat & 0.18176758 & & 0.694021541 & \\
\hline t Critical two-tail & 2.109815578 & & 2.364624252 & \\
\hline
\end{tabular}

In order to ascertain any significant difference between the pre-event window abnormal returns $(-15$ to $-1)$ and post event window abnormal returns ( +1 to 15$)$ for 15 days event window and 7 days $(-7$ to -1 and +1 to 15) event window student $t$ test was run. It is evident from the above the table No. 4.1 that for Sensex as the $t$ value 0.243729224 is less than the t critical two-tail value (2.10092204), therefore, we cannot reject the null hypothesis, meaning that there is no significant difference between pre-event window abnormal returns and post event abnormal returns. In case of 7 days event window the $t$ stat is -0.84091193 which is less that the $t$ critical value two-tail 2.364624252, therefore, once again we cannot reject the null hypothesis. However, in case for Nifty fifty index for 15 days event window as the $t$ value -0.288521549 is less than the $t$ critical two-tail value (2.109815578), we cannot reject the null hypothesis, meaning that there is no significant difference between preevent window abnormal returns and post event window abnormal returns. In case of 7 days event window the $t$ stat was -0.84090103 which was less that the $t$ critical two-tail value 2.364624252 , therefore we cannot reject the null hypothesis. In the last chosen index (BSE 100) for 15 days event window as the t value 0.18176758 is less than the $t$ critical two-tail value (2.109815578), we cannot reject the null hypothesis, meaning that there is no significant difference between pre-event window abnormal returns and post event window abnormal returns. In case of 7 days event window the $t$ stat was 0.18176758 which was less that the $t$ critical two-tail value 2.364624252 , therefore we cannot reject the null hypothesis. It is evident from the above analysis that, the decision of demonetising the Rs. 500 and Rs.1000 face value currency have not affected Indian stock market for the fifteen days event window and seven days event window.

Graph 4.1: Graph Showing Abnormal Returns And T Stats

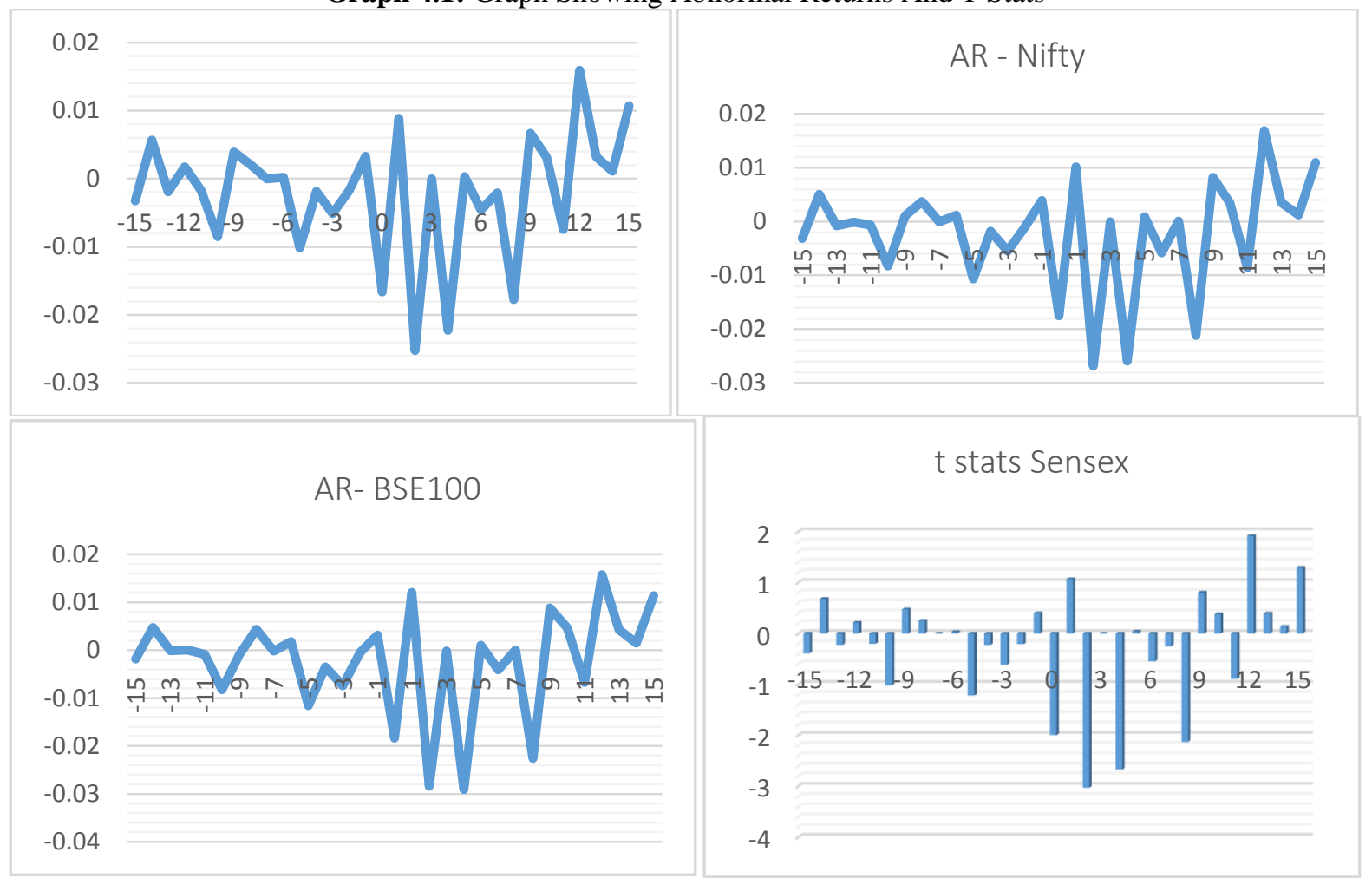




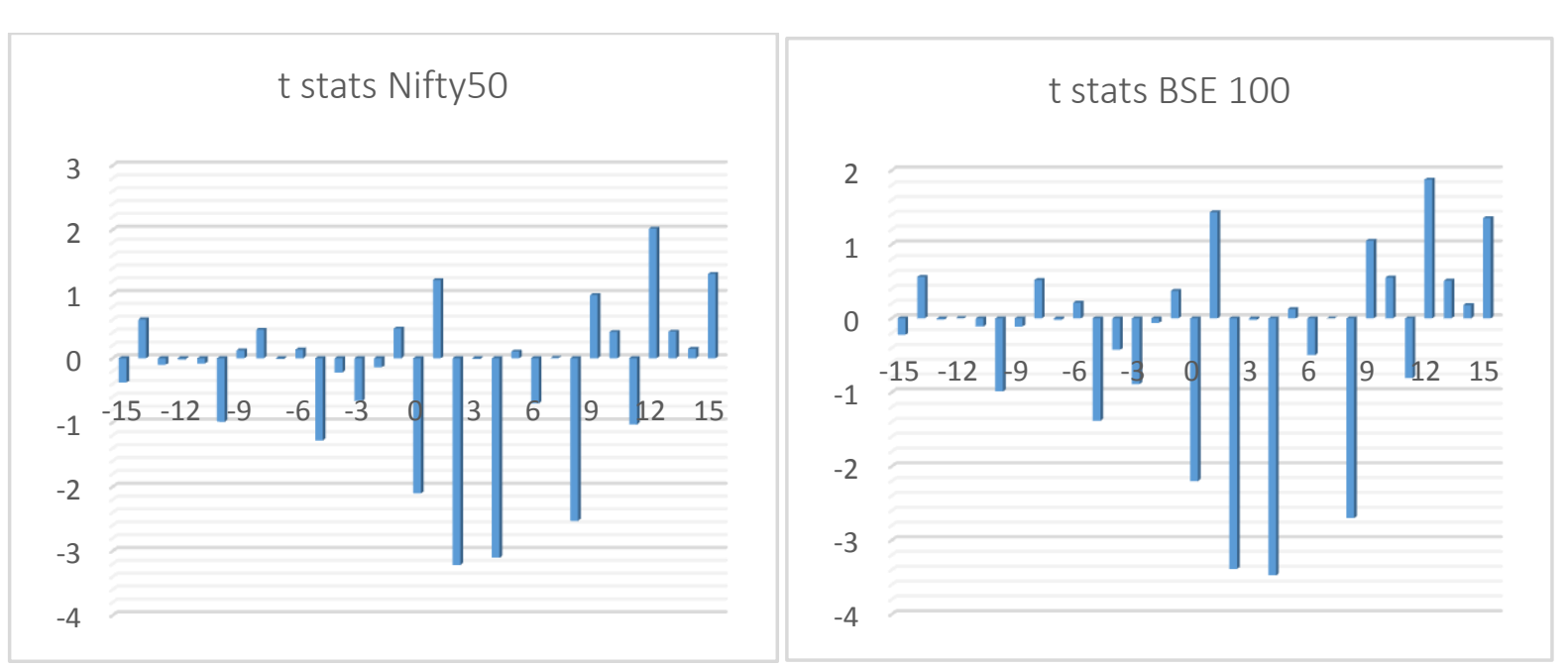

Table No. 4.2

\begin{tabular}{|l|l|l|r|l|r|r|r|}
\hline & Sensex & Nifty & BSE100 & & Sensex & Nifty & \multicolumn{1}{l|}{ BSE100 } \\
\hline SD -15 & 0.004401269 & 0.004348937 & 0.004626306 & -7 & 0.004343201 & 0.004774337 & 0.005281184 \\
\hline SD +15 & 0.011907597 & 0.013301261 & 0.014161992 & +7 & 0.012573086 & 0.014192205 & 0.015703474 \\
\hline Change & 0.007506328 & 0.008952324 & 0.009535687 & & 0.008229884 & 0.009417868 & 0.010422289 \\
\hline F & 7.319686852 & 9.354474738 & 9.370873087 & & 8.380381594 & 8.83636542 & 8.841557612 \\
\hline F Critical & 2.483725741 & 2.483725741 & 2.483725741 & & 4.283865714 & 4.283865714 & 4.283865714 \\
\hline & Reject & & Reject & & Reject & & Reject \\
\hline
\end{tabular}

\section{Table Showing Change In The Historical Volatility Returns For The Event Window}

This present study employs the historical volatility (standard deviation) and GARCH $(1,1)$ modelling technique to analyse the possible shift in volatility of the chosen indices (Sensex ,Nifty fifty and BSE100). In this case the standard deviation of the abnormal returns is taken as a measure of historical volatility of the both the indices. It is evident from the table No.4.2 that the SD of pre event of Sensex was 0.004401269 and for post event was 0.011907597 . Therefore in case of Sensex it has increased by 0.007506328 . The F value for Sensex was 7.319686852 which was greater than the critical value 2.483725741 therefore, we can reject the null hypothesis, meaning that there was a significant change in the historical volatility (standard deviation).

In case of Nifty Fifty pre event SD was 0.004348937 and post event it was 0.013301261 . The historical volatility in Nifty fifty increased by 0.008952324 . The F value for Nifty was 9.354474738 which was lesser than the critical value 2.483725741 therefore, we can reject the null hypothesis, meaning that there is a significant change in the historical volatility between pre-event window volatility (standard deviation) and post event volatility (standard deviation) in case of Nifty.

However, in case of BSE100 pre event SD was 0.004626306 and post event it was 0.014161992 . The historical volatility in Nifty fifty increased by 0.009535687 . The F value for Nifty was 9.370873087 which was lesser than the critical value 2.483725741 therefore, we can reject the null hypothesis, meaning that there is a significant change in the historical volatility between pre-event window volatility (standard deviation) and post event volatility (standard deviation) in case of BSE100.

That the SD of pre event in case of Sensex for 7 days event window was 0.004343201 and for post event was 0.012573086 . Therefore fore in case of Sensex it has gone up by 0.008229884 . In case of Nifty Fifty pre event the SD was 0.004774337 and post event it was 0.014192205 . Once again historical volatility in Nifty fifty was gone up by 0.009417868 . However, in case of BSE100 the SD before the event date was 0.005281184 and for post event it became 0.015703474. Therefore fore in case of BSE100 the SD has gone up by0.010422289.

In all the three chosen sectors we can reject the null hypothesis meaning that there is a significant change in the historical volatility between pre-event window volatility (standard deviation) and post event window volatility (standard deviation). 
Graph 4.2: Graph Showing Standard Deviation

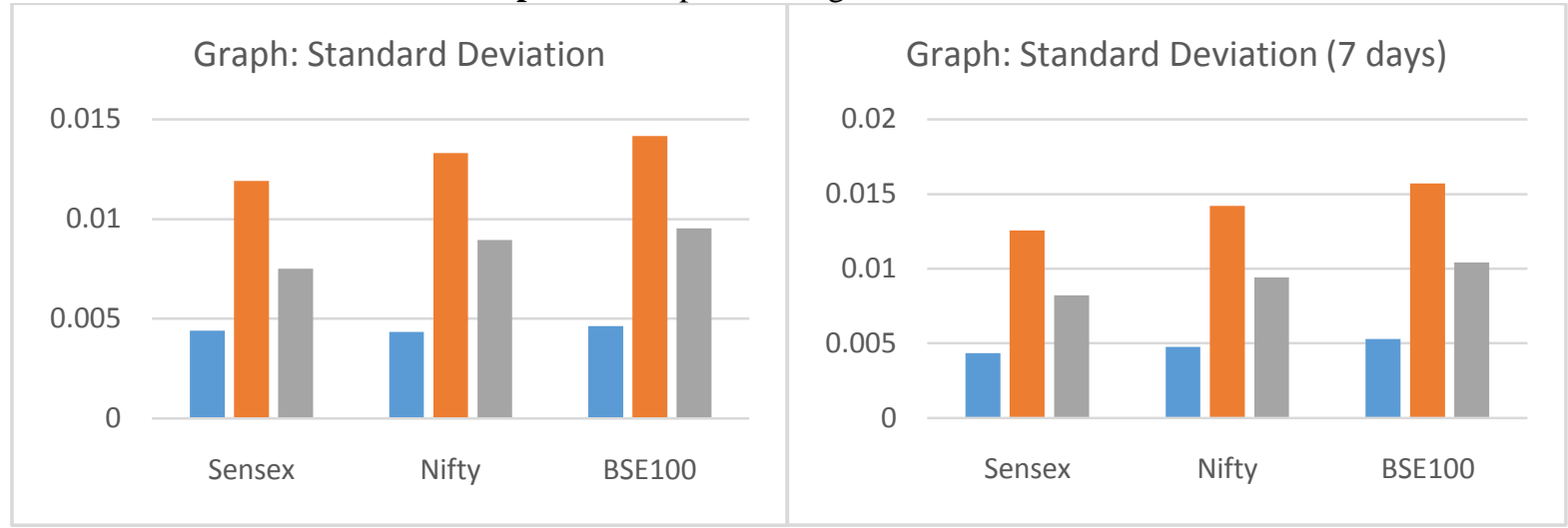

$\mathrm{ARCH}$ and GARCH models are commonly used in modelling a time series data that display timevarying volatility clustering (because the current period volatility can be affected by the previous period volatility, as volatility is time varying). ARCH-type models are sometimes considered to be in the family of stochastic volatility models, although this is strictly incorrect since at time $t$ the volatility is completely predetermined (deterministic) given previous values. The basic version of the least squares model assumes that the expected value of all error terms, when squared, is the same at any given point. This assumption is called homoskedasticity, and it is this assumption that is the focus of ARCH/ GARCH models. The review of literature also backing the time varying volatility by applying the ARCH and GARCH techniques (Bomfin, 2003). Therefore in the current study the GARCH model has been used to investigate the time varying volatility of pre-demonetisation and post demonetisation independently and later results are compared for predemonetisation and Post-demonetisation periods.

TABLE No. 4.3: Table Showing Changes In Persistence Volatility around Pre- and Post Event Window (Presence of Arch /Garch $(1,1)$ Effect)

\begin{tabular}{|c|c|c|c|c|c|c|c|c|}
\hline & \multicolumn{4}{|l|}{ Pre event } & \multicolumn{4}{|l|}{ Post event } \\
\hline & \multicolumn{2}{|l|}{$\left(\operatorname{RESID}(-1)^{\wedge} 2\right)$} & \multicolumn{2}{|c|}{ GARCH(-1) } & \multicolumn{2}{|c|}{$\left(\operatorname{RESID}(-1)^{\wedge} 2\right)$} & \multicolumn{2}{|c|}{ GARCH(-1) } \\
\hline & z-Stat & Prob. & z-Stat & Prob. & z-Stat & Prob. & z-Stat & Prob. \\
\hline Sensex (Y) & -2.152525 & 0.0314 & 0.673601 & 0.5006 & -1.917485 & 0.0552 & 3.607421 & 0.0003 \\
\hline Sensex (Y) & -0.729748 & 0.4655 & 0.796183 & 0.4259 & -1.941517 & 0.0522 & 1.223880 & 0.2210 \\
\hline Sensex (Y) & -0.918502 & 0.3584 & 0.642853 & 0.5203 & -1.531044 & 0.1258 & 2.063349 & 0.0391 \\
\hline Nifty (Y) & -1.045490 & 0.2958 & 0.456845 & 0.6478 & -1.152574 & 0.2491 & 2.157802 & 0.0309 \\
\hline Nifty (Y) & -0.801426 & 0.4229 & 0.463002 & 0.6434 & -0.552794 & 0.5804 & 1.112193 & 0.2661 \\
\hline Nifty (Y) & -183.7819 & 0.0000 & 0.430568 & 0.6668 & -1.539992 & 0.1236 & 2.018903 & 0.0435 \\
\hline BSE100 & -0.573054 & 0.5666 & 1.235580 & 0.2166 & -1.111780 & 0.2662 & 2.353275 & 0.0186 \\
\hline BSE100 & -0.381378 & 0.7029 & 0.391737 & 0.6953 & -0.552794 & 0.5804 & 1.112193 & 0.2661 \\
\hline BSE100 & -0.831303 & 0.4058 & 2.886688 & 0.0039 & -1.896830 & 0.0579 & 2.926988 & 0.0034 \\
\hline
\end{tabular}

The indices (Sensex and Nifty) were grouped on the basis of existence of ARCH and GARCH effect before and after the demonetisation decision. The above table No. 4.3 shows the changes in the volatility around the demonetisation decision. The volatility analyse the quality of volatility, meaning that current day's volatility due to state-of-the-art information would affect tomorrow's volatility or not. The model was run by employing all the three methods namely Normal Gaussian distribution, Student $t$ distribution and GED with fix parameter. In this case the ARCH effect signifies the effect of any state-of-the-art information that has come to the stock market. Therefore, any change in ARCH effect hints the effect of demonetisation on the stock market. It is evident from the above table that there was an ARCH effect in case of Sensex as per Normal Gaussian distribution, with Nifty as per GED with fix parameter and GARCH effect with BSE100 before the event under GED with fix parameter. However, when it comes to post demonetisation scenario, there was no ARCH effect among the chosen indices but there is a high degree of GARCH effect on all those chosen indices. For example for Sensex there was a GARCH effect under Normal Gaussian distribution and GED with fix parameter. For Nifty there was a GARCH effect under Normal Gaussian distribution and GED with fix parameter and in case of BSE100 also we can see the same evidence.

\section{Residual Diagnostics}

To investigate the existence of autocorrelation in the residuals Q - statistic test was conducted. If there is no serial correlation in the residuals, the autocorrelations and partial autocorrelations at all lags should be almost zero, and all Q-statistics should be insignificant with hefty p-values meaning that if the variance equation is perfectly specified, all Q-statistics should not be statistically significant. 
The Impact of Political Events on Stock Market Volatility: Evidence from Currency Demonetisation ..

Table No. 4.4: Correlogram Of Standardized Residuals - Q-Statistics ((Normal Gaussian Distribution, Student T Distribution And Ged With Fix Parameters) - Pre Event

\begin{tabular}{|c|c|c|c|c|c|c|c|c|c|c|c|c|}
\hline & \multicolumn{6}{|c|}{ Sensex } & \multicolumn{6}{|c|}{ Nifty } \\
\hline & \multicolumn{2}{|c|}{ N Gaussian D } & \multicolumn{2}{|c|}{ t distribution } & \multicolumn{2}{|c|}{ GED } & \multicolumn{2}{|c|}{ N Gaussian D } & \multicolumn{2}{|c|}{ t distribution } & \multicolumn{2}{|c|}{ GED } \\
\hline 2 & 0.0439 & 0.978 & 0.2686 & 0.874 & 0.1431 & 0.931 & 0.1568 & 0.925 & 0.2743 & 0.872 & 0.1532 & 0.926 \\
\hline 3 & 0.3545 & 0.949 & 0.9061 & 0.824 & 0.7197 & 0.869 & 1.4505 & 0.694 & 1.8531 & 0.603 & 1.8281 & 0.609 \\
\hline 4 & 7.2074 & 0.125 & 7.5137 & 0.111 & 7.3149 & 0.120 & 8.4000 & 0.078 & 8.5938 & 0.072 & 8.2147 & 0.084 \\
\hline 5 & 8.3169 & 0.140 & 8.2371 & 0.144 & 8.3098 & 0.140 & 9.7540 & 0.083 & 9.8650 & 0.079 & 9.6713 & 0.085 \\
\hline 6 & 8.3291 & 0.215 & 8.3756 & 0.212 & 8.3948 & 0.211 & 10.051 & 0.123 & 10.350 & 0.111 & 10.126 & 0.119 \\
\hline 7 & 8.4073 & 0.298 & 8.4860 & 0.292 & 8.5329 & 0.288 & 10.901 & 0.143 & 11.208 & 0.130 & 11.134 & 0.133 \\
\hline 8 & 9.3422 & 0.314 & 9.0361 & 0.339 & 9.1487 & 0.330 & 11.222 & 0.189 & 11.410 & 0.180 & 11.278 & 0.186 \\
\hline 9 & 13.001 & 0.163 & 12.317 & 0.196 & 12.756 & 0.174 & 16.566 & 0.056 & 16.912 & 0.050 & 16.923 & 0.050 \\
\hline 10 & 13.018 & 0.223 & 12.388 & 0.260 & 12.778 & 0.236 & 16.582 & 0.084 & 16.957 & 0.075 & 16.926 & 0.076 \\
\hline 11 & 13.076 & 0.288 & 12.406 & 0.334 & 12.818 & 0.305 & 16.981 & 0.108 & 17.318 & 0.099 & 17.338 & 0.098 \\
\hline 12 & 13.087 & 0.363 & 12.407 & 0.414 & 12.818 & 0.382 & 17.010 & 0.149 & 17.412 & 0.135 & 17.512 & 0.131 \\
\hline
\end{tabular}

\begin{tabular}{|c|r|r|r|r|r|}
\hline \multicolumn{9}{|c|}{ BSE100 } \\
\hline N Gaussian D & \multicolumn{2}{c|}{ t distribution } & \multicolumn{2}{c|}{ GED } \\
\hline Q-Stat & Prob* $^{*}$ & Q-Stat & \multicolumn{1}{c|}{ Prob* } & \multicolumn{1}{c|}{ Q-Stat } & Prob* $^{*}$ \\
\hline 1.4783 & 0.224 & 0.8695 & 0.351 & 1.6505 & 0.199 \\
\hline 1.4904 & 0.475 & 0.8735 & 0.646 & 1.6965 & 0.428 \\
\hline 2.6719 & 0.445 & 3.0682 & 0.381 & 3.4749 & 0.324 \\
\hline 7.5881 & 0.108 & 8.2115 & 0.084 & 7.7053 & 0.103 \\
\hline 7.9656 & 0.158 & 8.9838 & 0.110 & 7.8085 & 0.167 \\
\hline 8.2834 & 0.218 & 9.6285 & 0.141 & 8.3965 & 0.210 \\
\hline 9.5805 & 0.214 & 10.885 & 0.144 & 9.9526 & 0.191 \\
\hline 9.6246 & 0.292 & 10.897 & 0.208 & 9.9742 & 0.267 \\
\hline 14.604 & 0.102 & 15.447 & 0.079 & 14.311 & 0.112 \\
\hline 15.922 & 0.102 & 16.132 & 0.096 & 15.459 & 0.116 \\
\hline 17.633 & 0.090 & 17.005 & 0.108 & 16.913 & 0.110 \\
\hline 17.677 & 0.126 & 17.005 & 0.149 & 16.914 & 0.153 \\
\hline
\end{tabular}

Table No. 4.5: Correlogram of Standardized Residuals - Q-Statistics ((Normal Gaussian distribution, Student T Distribution And Ged With Fix Parameters) - Post Event

\begin{tabular}{|c|c|c|c|c|c|c|c|c|c|c|c|c|}
\hline & \multicolumn{6}{|c|}{ Sensex } & \multicolumn{6}{|c|}{ Nifty } \\
\hline & \multicolumn{2}{|c|}{ N Gaussian D } & \multicolumn{2}{|c|}{ t distribution } & \multicolumn{2}{|c|}{ GED } & \multicolumn{2}{|c|}{ N Gaussian D } & \multicolumn{2}{|c|}{ t distribution } & \multicolumn{2}{|c|}{ GED } \\
\hline & $\begin{array}{c}\text { Q- } \\
\text { Stat }\end{array}$ & Prob* & $\begin{array}{c}\text { Q- } \\
\text { Stat }\end{array}$ & Prob* & Q-Stat & Prob* & $\begin{array}{c}\text { Q- } \\
\text { Stat }\end{array}$ & Prob* & $\begin{array}{c}\text { Q- } \\
\text { Stat }\end{array}$ & Prob* & $\begin{array}{c}\text { Q- } \\
\text { Stat }\end{array}$ & Prob* \\
\hline 1 & 0.0282 & 0.867 & 3.1157 & 0.078 & 2.3606 & 0.124 & 2.2093 & 0.137 & 1.6810 & 0.195 & 3.1886 & 0.074 \\
\hline 2 & 0.5364 & 0.765 & 4.6016 & 0.100 & 3.5556 & 0.169 & 2.7799 & 0.249 & 1.8573 & 0.395 & 4.7022 & 0.095 \\
\hline 3 & 2.2109 & 0.530 & 5.2957 & 0.151 & 4.4523 & 0.217 & 3.6304 & 0.304 & 3.3770 & 0.337 & 5.0882 & 0.165 \\
\hline 6 & 2.8820 & 0.824 & 6.0925 & 0.413 & 5.2235 & 0.515 & 4.6140 & 0.594 & 4.8851 & 0.559 & 5.7997 & 0.446 \\
\hline 7 & 5.6785 & 0.578 & 6.7324 & 0.457 & 5.8889 & 0.553 & 5.9859 & 0.541 & 7.2612 & 0.402 & 6.3058 & 0.505 \\
\hline 8 & 6.8241 & 0.556 & 9.3447 & 0.314 & 8.7962 & 0.360 & 7.2227 & 0.513 & 8.1514 & 0.419 & 8.8363 & 0.356 \\
\hline 9 & 6.9597 & 0.641 & 11.696 & 0.231 & 11.055 & 0.272 & 9.7887 & 0.368 & 10.096 & 0.343 & 11.439 & 0.247 \\
\hline 10 & 11.800 & 0.299 & 17.965 & 0.056 & 16.592 & 0.084 & 15.919 & 0.102 & 15.307 & 0.121 & 17.104 & 0.072 \\
\hline
\end{tabular}

\begin{tabular}{|c|c|c|r|r|r|}
\hline \multicolumn{9}{|c|}{ BSE100 } \\
\hline N Gaussian D & \multicolumn{2}{c|}{ t distribution } & \multicolumn{2}{c|}{ GED } \\
\hline Q-Stat & Prob* $^{*}$ & Q-Stat & \multicolumn{1}{c|}{ Prob* } & Q-Stat $^{*}$ & Prob $^{*}$ \\
\hline 1.5641 & 0.211 & 1.6810 & 0.195 & 0.5641 & 0.453 \\
\hline 1.7946 & 0.408 & 1.8573 & 0.395 & 0.8727 & 0.646 \\
\hline 2.9250 & 0.403 & 3.3770 & 0.337 & 2.7260 & 0.436 \\
\hline 3.4126 & 0.491 & 4.1386 & 0.388 & 3.2593 & 0.515 \\
\hline 3.4246 & 0.635 & 4.1827 & 0.523 & 3.4310 & 0.634 \\
\hline 3.9712 & 0.681 & 4.8851 & 0.559 & 3.9367 & 0.685 \\
\hline 6.0845 & 0.530 & 7.2612 & 0.402 & 6.3407 & 0.501 \\
\hline 7.2860 & 0.506 & 8.1514 & 0.419 & 7.7197 & 0.461 \\
\hline 9.5400 & 0.389 & 10.096 & 0.343 & 8.7802 & 0.458 \\
\hline 14.503 & 0.151 & 15.307 & 0.121 & 13.670 & 0.189 \\
\hline 15.180 & 0.174 & 16.324 & 0.130 & 13.841 & 0.242 \\
\hline 16.641 & 0.164 & 18.142 & 0.111 & 14.259 & 0.285 \\
\hline
\end{tabular}


The Impact of Political Events on Stock Market Volatility: Evidence from Currency Demonetisation ..

The test accepts the null hypothesis of no auto correlation in the time series data. The above correlogram of squared residuals test results indicate that the residuals are not auto correlated.

Table No. 4.6: Normality Test - Jarque-Bera Statistics
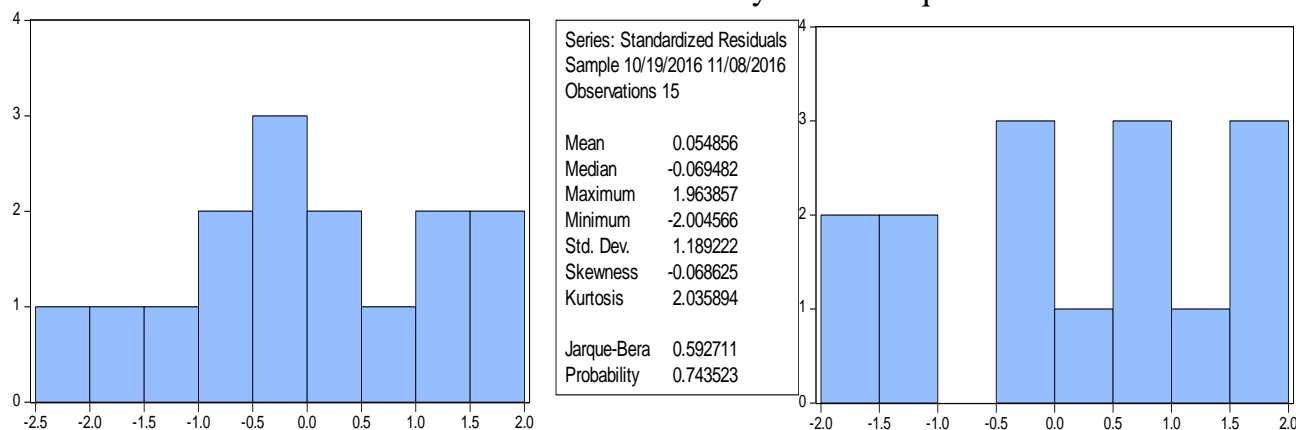

\begin{tabular}{|lc}
\hline \multicolumn{2}{|l}{ Series: Standardized Residuals } \\
Sample 10/19/2016 & $11 / 08 / 2016$ \\
Observations & 15 \\
& \\
Mean & 0.134831 \\
Median & 0.003216 \\
Maximum & 1.996811 \\
Minimum & -1.949582 \\
Std. Dev. & 1.206760 \\
Skewness & -0.108519 \\
Kurtosis & 1.974127 \\
& \\
Jarque-Bera & 0.687200 \\
Probability & 0.709212 \\
\hline
\end{tabular}
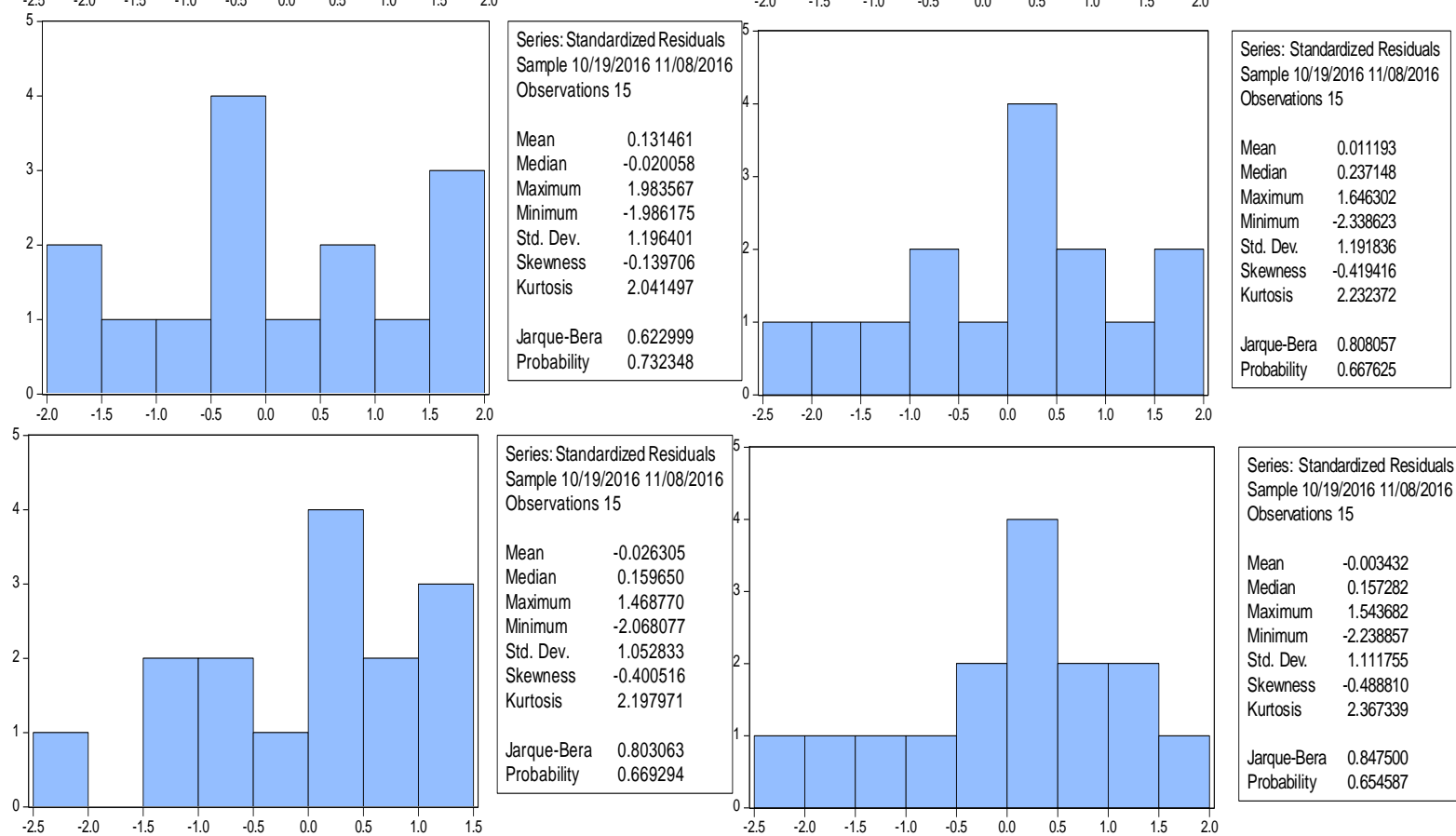

\begin{tabular}{|lc|}
\hline Series: Standardized Residuals \\
Sample 10/19/2016 11/08/2016 \\
Observations 15 \\
Mean & -0.003432 \\
Median & 0.157282 \\
Maximum & 1.543682 \\
Minimum & -2.238857 \\
Std. Dev. & 1.111755 \\
Skewness & -0.488810 \\
Kurtosis & 2.367339 \\
& \\
Jarque-Bera & 0.847500 \\
Probability & 0.654587 \\
\hline
\end{tabular}
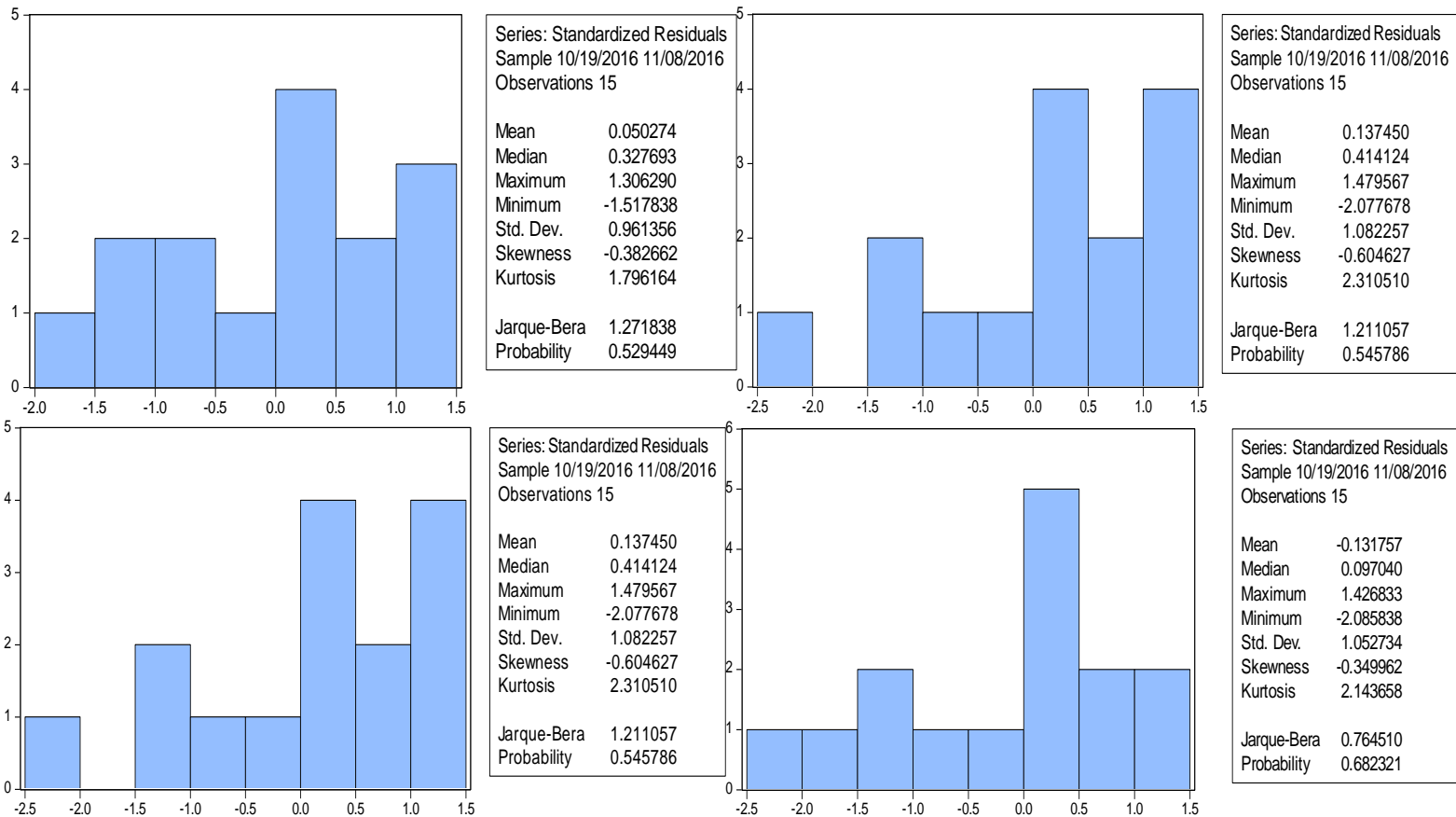
The Impact of Political Events on Stock Market Volatility: Evidence from Currency Demonetisation ..
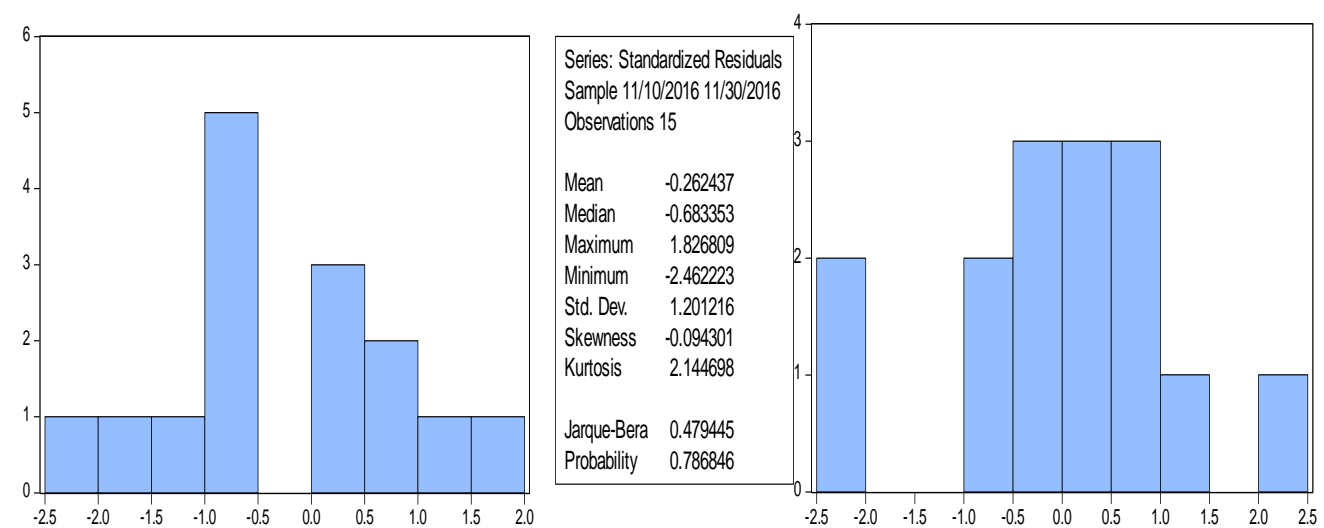

Series: Standardized Residuals

Sample 11/10/2016 11/30/2016

Observations 15

Median $\quad 0.129249$

Maximum 2.114365

Minimum $\quad-2.483254$

Std. Dev. 1.206436

Skewness $\quad-0.470661$

Kurtosis $\quad 2.846369$

Jarque-Bera 0.568556

Probability $\quad 0.752558$
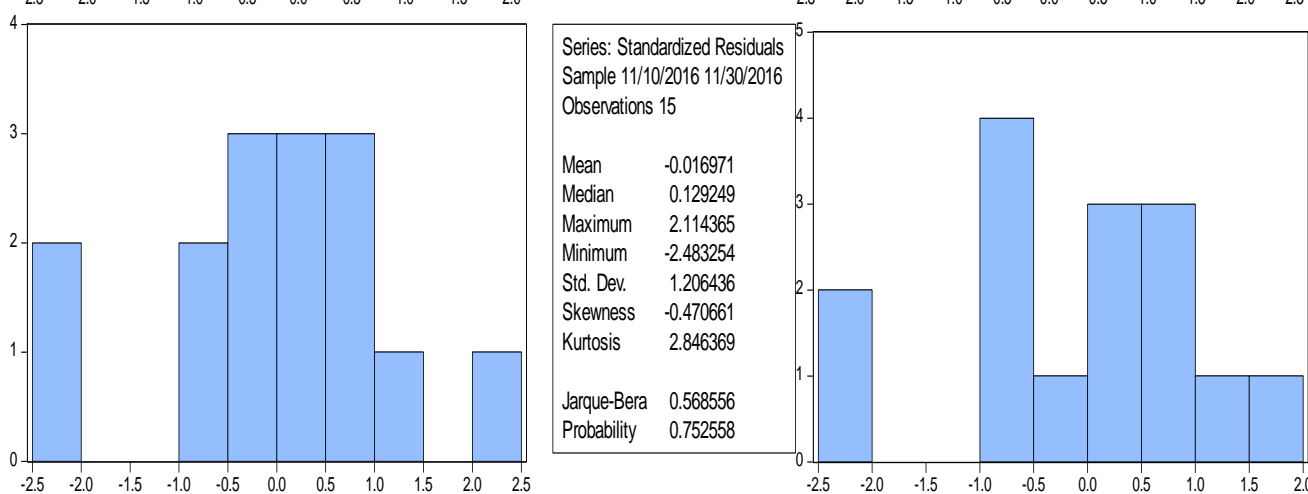

Series: Standardized Residuals

Sample 11/10/2016 11/30/2016

Observations 15

Mean $\quad-0.052232$

Median $\quad 0.226290$

Maximum 1.969496

Minimum $\quad-2.409606$

Std. Dev. $\quad 1.188754$

Skewness $\quad-0.485429$

Kurtosis $\quad 2.695267$

Jarque-Bera $\quad 0.647142$

Probability $\quad 0.723561$
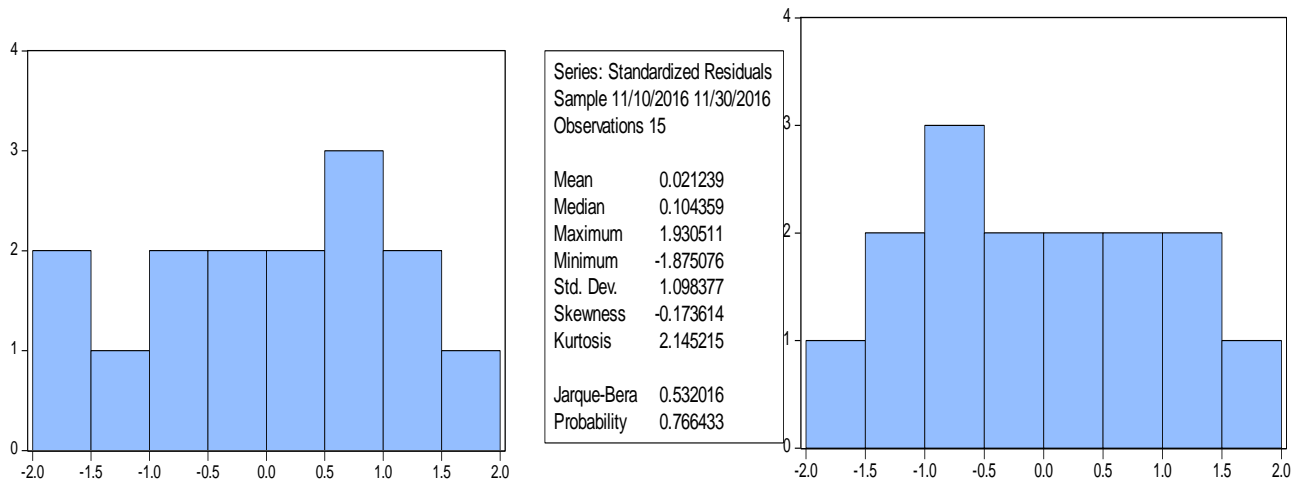

Series: Standardized Residuals Sample 11/10/2016 11/30/2016

Observations 15

Mean $\quad-0.051018$

Median $\quad-0.147206$

Maximum $\quad 1.793399$

Minimum $\quad-1.752588$

Std. Dev. $\quad 1.042149$

Skewness $\quad 0.007265$

Kurtosis $\quad 1.965608$

Jarque-Bera $\quad 0.668861$

Probability $\quad 0.715746$
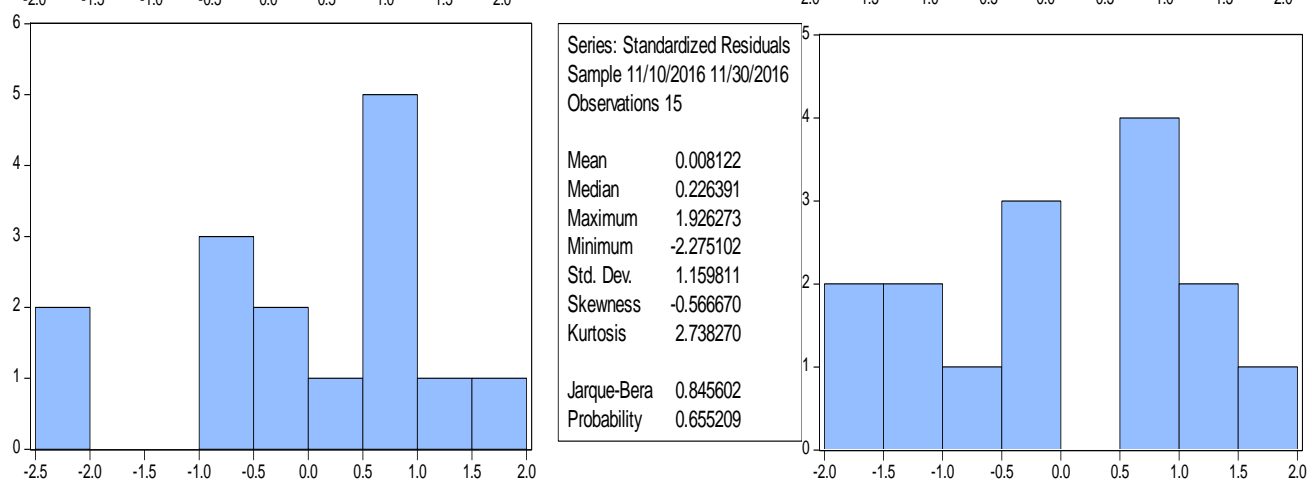

Series:Standardized Residuals

Sample 11/10/2016 11/30/2016

Observations 15

Mean $\quad-0.00461$

Median $\quad-0.015929$

$\quad 1.909748$

Minimum $\quad-1.843917$

Std. Dev. $\quad 1.136030$

Skewness $\quad-0.150622$

Kurtosis $\quad 1.981872$

Jarque-Bera $\quad 0.70458$ Probability $\quad 0.703075$
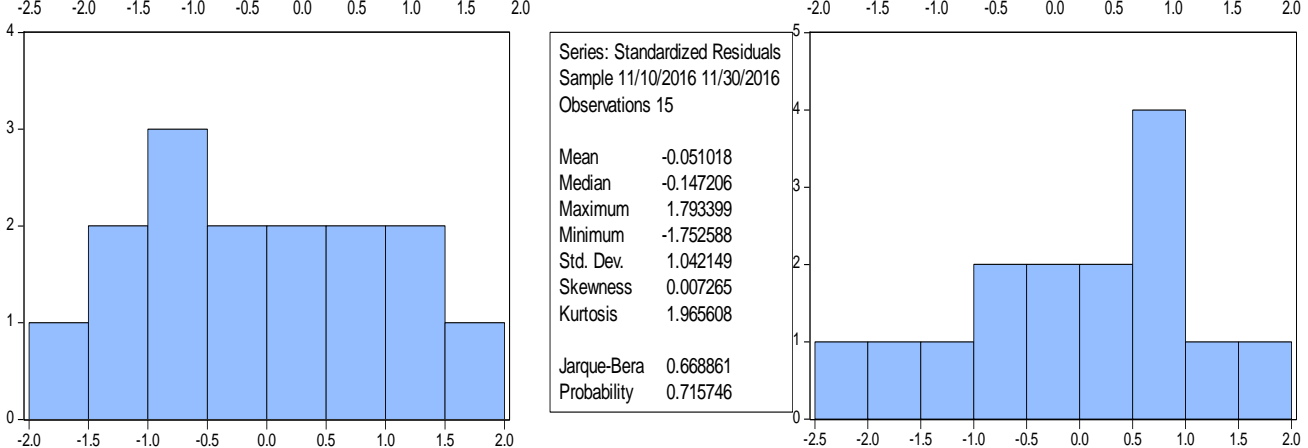

Series: Standardized Residuals Sample 11/10/2016 11/30/2016 Observations 15

$\begin{array}{ll}\text { Median } & 0.065777 \\ & \end{array}$

Minimum $\quad-2.205910$

Std Dev. $\quad 1.200554$

Stem 0.358885

Kurtosis $\quad 2.284186$

Jarque-Bera $\quad 0.644036$

Probability $\quad 0.72468$ 
In order to investigate the normality of the data distribution Jarque-Bera test for normality has been conducted. It is evident from the above table that the residuals are normally distributed.

Table No. 4.8: Arch Effect Test - (Normal Gaussian Distribution, Student T Distribution And Ged With Fix Parameters)

\begin{tabular}{|c|c|c|c|c|c|c|c|}
\hline \multicolumn{4}{|c|}{ Sensex } & \multicolumn{4}{|c|}{ Nifty } \\
\hline \multicolumn{2}{|c|}{ Pre Event } & \multicolumn{2}{|c|}{ Post Event } & \multicolumn{2}{|c|}{ Pre Event } & \multicolumn{2}{|c|}{ Post Event } \\
\hline Obs*R Sq & Prob. & $\begin{array}{l}\text { Obs*R- } \\
\text { squared }\end{array}$ & Prob. & $\begin{array}{l}\text { Obs*R- } \\
\text { squared }\end{array}$ & Prob. & $\begin{array}{l}\text { Obs*R- } \\
\text { squared }\end{array}$ & Prob. \\
\hline 0.102341 & 0.7490 & 0.041905 & 0.8378 & 1.369454 & 0.2419 & 0.887655 & 0.3461 \\
\hline 0.006315 & 0.9367 & 0.490550 & 0.4837 & 1.043695 & 0.3070 & 0.866219 & 0.3520 \\
\hline 0.091095 & 0.7628 & 0.946182 & 0.3307 & 1.684780 & 0.1943 & 0.710147 & 0.3994 \\
\hline \multicolumn{4}{|c|}{ BSE100 } & & & & \\
\hline \multicolumn{2}{|c|}{ Pre Event } & \multicolumn{2}{|c|}{ Post Event } & & & & \\
\hline Obs*R Sq & Prob. & $\begin{array}{l}\text { Obs*R- } \\
\text { squared }\end{array}$ & Prob. & & & & \\
\hline 0.083489 & 0.7726 & 1.881032 & 0.1702 & & & & \\
\hline 0.503999 & 0.4777 & 0.866219 & 0.3520 & & & & \\
\hline 0.185810 & 0.6664 & 1.552241 & 0.2128 & & & & \\
\hline
\end{tabular}

To investigate the presence of heteroscedasticity in the distribution of the residuals, an ARCH test was conducted for all the parameters (Normal Gaussian distribution, Student t distribution and GED with fix parameters). The ARCH test results indicate that there are no ARCH effects in the collected distribution. In other words, there is no heteroscedasticity in the residuals; thus, the residuals can be said to be homoscedastic.

\section{Discussion And Conclusion}

The current empirical study has been undertaken to understand the impact of the central government decision of withdrawing higher denomination currency from circulation on Indian benchmark indices Sensex, Nifty fifty and BSE100 indices. In order to realise the stated objectives the researchers have collected the data from 26-10-2015 to 30-11-2016 from the capital line data base. The collected data has been tested for stationarity by using ADF test. An event study methodology has been employed to ascertain the abnormal returns (AR) and student t test has been used to test the significance. For the purpose of the study the date on which the demonetisation announcement came out were taken as the event date $(t=0)$. The thirty one days enclosing the referendum (i.e., $\mathrm{t}=-15, \ldots \ldots, 0 \ldots,+15$ ) is labelled as the event window. Further, to investigate the time varying volatility GARCH $(1,1)$ model has been applied.

The current study revealed that in case of BSE100 the highest AR recorded in the pre-event period ranging from the lowest value of -0.0116064413685003 on day -5 to the highest value of 0.004701071 on day 14. However, in the post-event period the highest AR recorded ranging from the lowest value of 0.029144016 on day 4 to the highest value of 0.0 .0157436092148135 on day 12 . On the event day i.e. announcement day the abnormal returns were -0.018449605 with a $t$ value of -2.1982203 . However, none of the Abnormal Return (AR) were statistically significant at $5 \%$ other than day the event day $(0), 2^{\text {nd }}$ day (with an abnormal return of 0.02842942 with a $t$ value of -3.387288313 ), on day 8 (with an AR of -0.022651876 with a $t$ value of 2.698909621) and day 4. Therefore, we can conclude that the decision of demonetisation of Rs. 500 and Rs. 1000 currency notes have an impact on BSE 100 Index on the event day. Therefore, we can conclude that demonetisation referendum has an impact on BSE100 on the event day.

However, in case of Nifty fifty, it was observed that the highest Abnormal Return (AR) recorded in the pre-event period ranging from the lowest value of -0.010706433 on day - 5 to the highest value of 0.005031266 on day -14. However, in the post-event period the highest Abnormal Return (AR) recorded ranging from the lowest value of -0.026884853 on day 2 to the highest value of 0.016848565 . On the event day (0) the abnormal returns were -0.017557405 with a $t$ value of -2.10128197 (statistically significant). In case of the Nifty 50 results show that in -15 to +15 days event window period, none of the Abnormal Return (AR) were statistically significant at conventional level of $5 \%$ other than for day 2 , day 4, on day 8 , on day twelfth and on the event day (0). Therefore, we can conclude that decision of demonetising the currency has an impact on Nifty Index.

In case of BSE Sensex, it was observed that the highest Abnormal Return (AR) recorded in the preevent period ranging from the lowest value of -0.0101515476237689 on day -5 to the highest value of 0.005663454 on day -14 . However, in the post-event period the highest Abnormal Return (AR) recorded ranging from the lowest value of -0.025237636 on day 2 to the highest value of 0.015938895 on day 12 . On the event day (0) the abnormal returns were -0.016621546 . The Sensex results show that in -15 to +15 days event window period, none of the Abnormal Return (AR) were statistically significant at conventional level of 5\% other than for day 2 , day 4 , on day 8 and on the event day (0). Therefore, we can conclude that decision of demonetising the currency has an impact on BSE Sensex Index. 
In order to capture the historical volatility (standard deviation) $\mathrm{F}$ test has been conducted. In this case the standard deviation of the abnormal returns is taken as a measure of historical volatility of the both the indices. The SD of pre event of Sensex was 0.004401269 and for post event was 0.011907597. Therefore in case of Sensex it has increased by 0.007506328 . The F value for Sensex was 7.319686852 which was greater than the critical value 2.483725741 therefore, we can reject the null hypothesis, meaning that there was a significant change in the historical volatility (standard deviation). In case of Nifty Fifty pre demonetisation (event) SD was 0.004348937 and post event it was 0.013301261 . The historical volatility in Nifty fifty increased by 0.008952324 . The F value for Nifty was 9.354474738 which was lesser than the critical value 2.483725741 therefore, we can reject the null hypothesis, meaning that there is a significant change in the historical volatility. However, in case of BSE100 pre event SD was 0.004626306 and post event it was 0.014161992 . The historical volatility in Nifty fifty increased by 0.009535687 . The F value for Nifty was 9.370873087 which was lesser than the critical value 2.483725741 therefore, we can reject the null hypothesis, meaning that there is a significant change in the historical volatility between pre-event window volatility (standard deviation) and post event volatility (standard deviation) in case of BSE100. Similar findings were noted even for 7 days period.

The indices (Sensex, Nifty and BSE100) were grouped on the basis of existence of ARCH and GARCH effect before and after the demonetisation event. To capture the time varying volatility of predemonetisation and post demonetisation independently. Any change in ARCH effect hints the effect of demonetisation on the stock market. There was an ARCH effect in case of Sensex as per Normal Gaussian distribution, with Nifty as per GED with fix parameter and GARCH effect with BSE100 before the event under GED with fix parameter. However, when it comes to post demonetisation scenario, there was no ARCH effect among the chosen indices but there is a high degree of GARCH effect on all those chosen indices. For example for Sensex there was a GARCH effect under Normal Gaussian distribution and GED with fix parameter. For Nifty there was a GARCH effect under Normal Gaussian distribution and GED with fix parameter and in case of BSE100 also we can see the same evidence. This concludes that there is a high degree of risk after the event.

On the event day there was a violent fluctuations in the stock market (the BSE Sensex opened with a massive loss of 1,300 points, although recovered later) and there was a temporary setback for few sector specific stocks such as steel, real estate, cement, auto, jewellery etc. This is because the economy would experiencing the sudden short of the required money needed to enable the transactions. The money needed to buy the goods and services would expected to reduce considerably. This phenomena is expected to continue for two more quarters at least as the demand for goods and services are the function of money supply in the economy. But it is expected to stabilise over a period of time. Experts are anticipating a correction of 20-30\% in case of real estate sector. It is in turn expected to reduce the inflation in the nation and growth rate is expected to increase at least after a year. Stock market is expected to be benefit by this move because, the economy is gradually shifting from physical assets to financial assets. Government is expected to collect more public revenue in the form of direct taxes and this can be utilised to for public spending. This move is expected to reduce corruption staggeringly. This in turn is expected to increase the rate of employment in the nation. As per the outlook of Indian economy predicted by the various agencies the interest rates are likely to fall and inflation is likely to fall. Couple of banks have already reduced the interest rate on long term fixed deposits. This action is expected to increase the bonds rate. When banks are offering less interest rate, investors are expected to shift their investments from banks to mutual funds or stock market especially fundamentally strong blue chip stocks or even gold ETFs. According to an analyst the effect on gold is bit uncertain may be negative or neutral. Banking sector is expected to enjoy the demonetisation as the new legal money is expected to enter into the system. Large cash deposits would help the banking sector in the long run. Who knows, Modi's dream of getting India to the top 10 in Ease of doing business rankings may come true in the distant future.

\section{References}

[1] Abidin, S.Z., Old, C. \& Martin, T. (2010). "Effects of New Zealand general elections on stock market returns". International Review of Business Research Papers, 6(6), 1-12.

[2] Acemoglu, Daron, Simon Johnson, James Robinson, and Yungyong Thaicharoen (2003), "Institutional causes, macroeconomic symptoms: volitily, crises and growth", Journal of Monetary Economics, 50, 49-123.

[3] Aggarwal, R. (2003). "Exchange rates and stock prices: A study of the US capital markets under floating exchange rates". Akron Business and Economic Review, 12, 7-12.

[4] Alexander, S. (1961). "Price Movements in Speculative Markets: Trends or Random Walk," Industrial Management Review, Vol.2.7-26.

[5] Allvine FC, O'Neill DE (1980). "Stock market returns and the presidential election cycle/implications for market efficiency". Financial Analysts Journal.36:49-56.

[6] Anderson, H. D., Malone, C. B., \& Marshall, B. R. (2008). "Investment returns under right-and left-wing governments in Australasia”. Pacific-Basin Finance Journal, 16(3), 252-267.

[7] Angboza, Lazarov A. and Ranga Narayanan (1996), "Catastrophic Shocks in the Property- Liability Insurance Industry: Evidence on Regulatory and Contagion Effects", The Journal of Risk and Insurance, Vol. 63, No. 4, pp. 619-637.

[8] Arzu, S. (2011), "Political Instability \& Its Impact on Karachi Stock Exchange”. Working paper, Lahore School of economics. Chan, Y. C., \& John, W. K. (1996). Political risk and stock price volatility: the case of Hong Kong. Pacific-Basin Finance Journal, $4(2), 259-275$ 
[9] Asprem, M. (1989). "Stock prices, asset portfolios and macroeconomic variables in ten European countries". Journal of Banking and Finance, 13(4/5), 589-612.

[10] Babu, M. S., \& Prabheesh, K. (2007). "Causal Relationships between Foreign Institutional Investments and stock returns in India". International Journal of Trade and Global Markets, Vol. 1 No. 3, 259-265.

[11] Babu, S.Suresh and Venkateswarlu (2013). "Impact of Union Budget on Indian Stock Prices". International Journal of Management Research and Review, Volume 3, Issue 5

[12] Bailey, Warren and Y. Peter Chung (1995), Exchange rate fluctuations, political risk, and stock returns: some evidence from an emerging market, Journal of Financial and Qualitative Analysis, 30 (4), December, 541-61.

[13] Ball, R., and P. Brown, “An Empirical Evaluation of Accounting Income Numbers,” Journal of Accounting Research 6, 1968, pp. 159-178.

[14] Beaulieu, M., Cosset, J., Essaddam, N., (2005), "The impact of political risk on the volatility of stock returns: The case of Canada", Journal of International business studies, 36, 701-718.

[15] Beaulieu, Marie-Claude, Jean-Claude Cosset, and Naceur Essaddam (2005), "The impact of political risk on the volatility of sock returns: the case of Canada", Journal of International Business Studies, 36 (6), November, 701-718.

[16] Bechtel, Michael M., and Roland Füss 2010. "Capitalizing on Partisan Politics? The Political Economy of Sector-Specific Redistribution in Germany." Journal of Money, Credit and Banking, 42(2-3): 203-35

[17] Bernanke BS, Kuttner KN (2005). "What Explains the Stock Market's Reaction to Federal Reserve Policy?" Journal of Finance. 60(3):1221-1257

[18] Beyer SB, Jensen GR, Johnson RR (2008). "The presidential term”. Journal of Portfolio Management. 135-142

[19] Bialkowski, J., Gottschalk, K., \& Wisniewski, T. P. (2008). "Stock Market Volatility around National Elections". Journal of Banking \& Finance, 32(9), 1941-1953.

[20] Bittlingmayer G., (1992). "Stock returns, real activity and the trust question", Journal of Finance, 47(5), 1701-30.

[21] Booth, J. R., \& Booth, L. C. (2003). "Is presidential cycle in security returns merely a reflection of business conditions?" Review of Financial Economics, 12(2), 131-159.

[22] Brooks, R.D, Faff, R.W. and Sokulsky, D.L. 2005. "The stock market impact of German reunification: international evidence", Applied Financial Economics, Vol. 15, No. 1, pp. 31-42.

[23] Cannella A, Hambrick D. Effects of executive departures on the performance of acquired firms. Strateg Manage J 1993; 14:137-52.

[24] Carhart MM. On persistence in mutual fund performance. Journal of Finance 1997;52(1):57-82.

[25] Cartaer, D. and Simkins, B. (2004). "The market's reaction to unexpected, catastrophic events: the case of airline stock returns and the September 11 the attacks". The Quarterly Review of Economics and Finance, 44, pp. 539-558

[26] Chaney, P. K., Devinney, T. M. and Winer, R. S. (1991). "The impact of new product introduction on the market value of firms", Journal of Business, 64 (4), pp. 573-610.

[27] Charest, G. (1978). "Dividend Information, Stock Returns and Market Efficiency-II". Journal of Financial Economics, Vol.12. 297330 .

[28] Chauvet and Collier (2008), "Elections and Economic Policy in Developing Countries", Economic Policy, 24:59, 509-550.

[29] Chen, S.S., Chen H.C., 2007. "Oil prices and real exchange rates". Energy Economics 29 (3), 390-404.

[30] Chopra, N., J. Lakonishok, \& J. Ritter. (1992). “Measuring Abnormal Performance: Do Stock Overreact?” Journal of Financial Economics, Vol.31. 235-268.

[31] Ciner C. (2001). "Energy Shocks and Financial Markets: Nonlinear Linkages". Studies in Non- Linear Dynamics and Econometrics. 5, 203-212.

[32] Clark, E., Masood, O. \& Tunaru, R. (2008), "The effect of political events on the Pakistan Stock Exchange 1947-2001". Investment Management and Financial Innovations, Volume 5, Issue 3, 2008.

[33] Collins, D., and W. Dent (1984). “A Comparison Of Alternative Testing Models Used In Capital Market Research,” Journal of Accounting Research. 22, pp. 48-84.

[34] Cook, T. and T. Hahn. (1989) "The Effect of Changes in the Federal Funds Rate Target on Market Interest Rates in the 1970s," Journal of Monetary Economics, 24(3), 331-51.

[35] Corrado, C. (1989). "A Nonparametric Test for Abnormal Security Performance in Event Studies," Journal of Financial Economics. 23, pp. 385-395.

[36] Coudert, V., Mignon, V., Penot, A., (2008). "Oil price and dollar". Energy Studies Review 15 (2), 48-65

[37] Cutler M. D., Poterba J. M., and Summers L. H., (1989). "What moves stock prices?” Journal of Portfolio Management, 15(3). 412.

[38] Das, S. R., Sen, P. K. and Sengupta, S. 1998. "Impact of strategic alliances on firm valuation" Academy of Management Journal, 41(1): pp. 27-41.

[39] DeFond ML, Konchitchki Y, McMullin JL, O'Leary DE (2010). "Does superior knowledge management increase shareholder value?" Paper presented at the American Accounting Association Annual Meeting, San Francisco, August

[40] Diamonte R., Liew. J., Stevens, R., 1996, "Political risk in emerging and developed markets", Financial Analysts Journal, 52 (3), 71-76.

[41] Dimitrova, D. (2005), "The Relationship between Exchange Rates and Stock Prices - Studied in Multivariate Model”, Issues in Political Economy, vol.14.

[42] Divya Verma Gakhar, Neha Kushwaha and Vinita Ashok (2015). "Impact of Union Budget on Indian Stock Market". Scholedge International Journal of Management \& Development. Vol.02, Issue 1. 21-36.

[43] Dolley, James C. (1933). "Characteristics and Procedure of Common Stock Split-Ups", Harvard Business Review, Volume 37, Issue 5. 316-326.

[44] Doong, S.-Ch., Yang, Sh.-Y., Wang, A., (2005). "The dynamic relationship and pricing of stocks and exchange rates: Empirical evidence from Asian emerging markets," Journal of American Academy of Business. Vol.7, No. 1. 118-23.

[45] Dopke, J and Pierdzioch, C. (2006). "Politics and the stock market: Evidence from Germany", European Journal of Political Economy, Vol. 22, No. 4. 925-943.

[46] Drazen A (2001). "The political business cycle after 25 years", NBER macroeconomics annual 2000. Cambridge MA: MIT Press, 15 , pp. $75-117$

[47] Elton, E., Gruber, M., Das, S., and Hlavka, M. (1993). "Efficiency with Costly Information: A Reinterpretation of Evidence from Managed Portfolios," The Review of Financial Studies, Vol.6. 1-22.

[48] Erb C., Harvey. C, Viskanta T., (1996). "Political risk, economic risk and financial risk", Financial Analysts Journal, Nov-Dec 1996. 
[49] Evelita E. Celis and Leow Jia Shen (2015). "Political Cycle and Stock Market - The Case of Malaysia”, Journal of Emerging Issues in Economics, Finance and Banking (JEIEFB). Vol. 4 Issue 1

[50] Fama EF (1970). "Efficient capital markets: a review of theory and empirical work". Journal of Finance. 25: 383-417.

[51] Fama, E. F. (1965). “The behaviour of stock-market prices", The Journal of Business, Vol. 38, No. 1. 34-105.

[52] Fama, F. (1981). "Stock Returns, Real Activity, Inflation, and Money". American Economic Review. 71: 545-565.

[53] Fleming, M.J. and E.M. Remolona. (1999) "Price Formation and Liquidity in the U.S. Treasury Market: The Response to Public Information," Journal of Finance, 54(5), 1901-15.

[54] Frey, B S \& Kucher, M 2000, "World War II as reflected on capital markets", Economics Letters Vol. 69, pp 187-191

[55] Gartner M (1994) "The quest for political cycles in OCED economies". European Journal of Political Economics. 10. 427-440

[56] Gartner M, Wellershoff KW (1995). "Is there an election cycle in American stock returns?" International Rev Econ Finance. 4(4). $387-410$

[57] Gärtner, Manfred/Wellershoff, Klaus W. (1995): Is there an Election Cycle in American Stock Returns?: International Review of Economics and Finance 4 (4): 387-410.

[58] Gemmill, G. (1992). "Political risk and market efficiency: tests based in British stock and options markets in the 1987 election". Journal of Banking and Finance, 16(1), 211-231.

[59] Goodell, J. W., \& Vähämaa, S. (2013). "U.S. Presidential elections and implied volatility: The role of political uncertainty". "Journal of Banking and Finance, 37. 1108-1117.

[60] Hamilton, J. D. (2003). What is an Oil Shock?" Journal of Econometrics, 113. 363-98.

[61] Hamilton, J.D. (2008) “Assessing Monetary Policy Effects Using Daily Federal Funds Futures Contracts," Federal Reserve Bank of St. Louis Review, 90(4). 377-93.

[62] Hamilton, James D., Herrera, M. Ana (2004), "Oil Shocks and Aggregate Macroeconomic Behaviour: The Role of Monetary Policy”, Journal of Money, Credit \& Banking Vol. 36, No.2. 265

[63] Hensel, C. R., \& Ziemba, W. T. (1995). "United States investment returns during Democratic and Republican administrations, 1928-1993”. Financial Analysts Journal. 61-69.

[64] Herron, Michael C., James Lavin, Donald Cram, and Jay Silver 1999. "Measurement of Political Effects in the United States Economy: A Study of the 1992 Presidential Election.” Economics and Politics 11(1): 51-81

[65] Hibbs, Jr. D. A (1977), "Political parties and macroeconomic policy", The American Political Science Review, Vol. 71, No. 4. 1467-1487.

[66] Huang, R. D. (1985). “Common stock returns and presidential elections”. Financial Analysts Journal, (March/April):58-61.

[67] James Ndungu Kabiru , Duncan Elly Ochieng, Hellen Wairimu Kinyua (2015). "The effect of general elections on stock returns at the Nairobi securities exchange". European Scientific Journal October edition vol.11, No.28.

[68] Jarrell, G., J. Brickley and J. Netter (1988), "The market for corporate control - The empirical evidence since 1980, Journal of Economic Perspectives 2: 49-68.

[69] Javid, A. Y. (2007). "Stock market reaction to catastrophic shock: Evidence from listed Pakistani firms". PIDE Working Papers, 37.

[70] Jensen, M. C. and Benington, G. A. (1970) "Random walks and technical theories: Some additional evidence", Journal of Finance, Vol. 25, No. 2. 469-482.

[71] Jensen, M., and R. Ruback, (1983), The market for corporate control - The scientific evidence, Journal of Financial Economics 11: $5-50$.

[72] Jeong B, Lu Y. The impact of radio frequency identification investment announcements on the market value of the firm. Journal of Theory Applied Electronic Commerce Res 2008;3(1):41-54 April.

[73] Johnson, R. R., Chittenden, W. T., \& Jensen, G. R. (1999). "Presidential politics, stocks, bonds, bills, and inflation". The Journal of Portfolio Management, 26. 27-31.

[74] Jones, Randall J. 2008. "The State of Presidential Election Forecasting: The 2004 Experience." International Journal of Forecasting 24(2): 310-21.

[75] Joseph, N. (2002). Modelling the impacts of interest rate and exchange rate changes on UK Stock Returns. Derivatives Use, Trading \& Regulation, 7(4), 306-323

[76] Kaur, Harvinder (2004). "Stock Market Volatility in India". The Indian Journal of Commerce, Volume 57, 4, 55-70.

[77] Kavussanos, M.G. and S.N. Marcoulis, (1997). "The stock market perception of industry risk and microeconomic factors: The case of the US water transportation industry versus other transport industries". Transportation Research. Part E, Logistics and Transportation Review 33: 147-158.

[78] Khakan Najaf, Rabia Najaf, Amir Iqbal, Imran Hussain Shah (2015). "The Impact of Terrorism and Political Events on Stock Market: Empirical Evidence from Pakistan". International Journal of scientific research and management (IJSRM). Volume 3 issue 6 June 2015. 3036-3045

[79] Khalid, Ahmed M. and Masahiro Kawai (2003), Was financial market contagion the source of economic crisis in Asia? Evidence using a multivariate VAR model, Journal of Asian Economics, 14(1), February, 133-159.

[80] Khalid, Ahmed M. and Rajaguru, Gulasekaran (2010). "The impact of political events on financial market volatility: Evidence using a Markov Switching process". Globalisation and Development Centre. Paper 43. http://epublications.bond.edu.au/gdc/43

[81] Kilian, L. (2008). "Exogenous Oil Supply Shocks: How Big Are They and How Much Do They Matter for the US Economy?" Review of Economics and Statistics 90, 216-40.

[82] Kim, Harold Y. and Jianping Mei (1999), "Political risk and stock returns: the case of Hong Kong", Stanford University Working Paper Series, September.

[83] Kim, k.-h. (2003). "Dollar exchange rate and stock price: Evidence from multivariate cointegration and error correction model". Review of Financial Economics. 301-313.

[84] Kim, S.-J., Nguyen, D.Q.T. (2008). "The reaction of the Australian financial markets to the interest rate news from the Reserve Bank of Australia and the U.S. Fed". Research in International Business and Finance 22, 378-395.

[85] Kithinji and Ngugi (2013). "Stock market performance before and after election: NSE Case study"

[86] Kongprajya, A. (2010), "An analysis of the impact of political news on Thai stock market".A Dissertation presented in part consideration for the degree of "MA Risk Management". University of Nottingham.

[87] Kothari S, Warner J. Econometrics of event studies (2006). "In: Espen Eckbo B, editor. Handbook of corporate finance: empirical corporate finance". Elsevier/North.

[88] Kothari, S., and J. Warner (1997), Measuring long-horizon security price performance, Journal of Financial Economics. 43: 301339.

[89] Kumar Deva B. , Sophia Sharon and Jucunda Evelyn Maria (2015). Empirical Study on Effects of the Lok Sabha Election on Stock Market Performance (BSE SENSEX), Research Journal of Management Sciences. Vol. 4(2), 1-9, February. 
[90] Kutchu, Vishal (2012). "Testing Semi-Strong Efficiency of Indian Stock Market - A Study on Effect of Union Budget 2012 on Six Select Sectorial Stocks". International Refereed Research Journal, Volume III, 3(2), 74.

[91] Lamasigi, T. A. (2002). Reaksi Pasar Modal Terhadap Peristiwa Pergantian Presiden Republik Indonesia 23 Juli 2001: Kajian Terhadap Return Saham LQ-45 di PT. Bursa Efek Jakarta [Stock Exchange's Reaction on the Changes of Indonesia's President on July, 23rd, 2001: Study on Return of LQ-45's stocks on Jakarta Stock Exchange]. Simposium Nasional Akuntansi V Semarang.

[92] Leblang, D. and Mukherjee, B. (2005), Government Partisanship, Elections, and the Stock Market: Examining American and British Stock Returns, 1930-2000

[93] Alesina, Alberto, and Jeffrey Sachs (1986). "Political Parties and the Business Cycle in the United States, 1948-1984." Journal of Money, Credit and Banking 20(1): 63-82.

[94] Leblang, David/Mukherjee, Bumba (2005): "Government Partisanship, Elections, and the Stock Market: Examining American and British Stock Returns". American Journal of Political Science: 49 (4): 780-802.

[95] LeDuc, L., \& Pammett, J. H. (2013). The fate of governing parties in times of economic crisis. Electoral Studies, 32(3), 494-499.

[96] Li J, Born JA (2006). "Presidential election uncertainty and common stock return in the United States". Journal of Finance Research. 29(4):609-622

[97] Lim, K. P, Brooks, R. D. and Hinich, M. J. 2008, 'Nonlinear serial dependence and the weakform efficiency of Asian emerging stock markets', Journal of International Financial Markets, Institutions and Money, vol. 18, pp. 527-44.

[98] Lin, C.T. \& Wang, Y.H. (2003), "The Impact of Political Uncertainty on the Stock Market: Evidence from Taiwan". Student Dissertation.

[99] Ling-Fang Liu (2007). An Empirical Study of the Presidential Elections Effect on Stock Market in Taiwan, South Korea, Singapore, Philippine and Indonesia

[100] Liu. (2007). "An Empirical Study of the Presidential Elections Effect on Stock Market in Taiwan, South Korea, Singapore, Philippine, and Indonesia". MA Finance and Investment, the University of Nottingham.

[101] Ma, Y., Sun, H.-L., \& Tang, A. P. (2003). "The return and volume effects of political-risk event on foreign joint ventures: Evidence from the Tiananmen Square crisis". Global Financial Journal, 49- 64.

[102] MacKinlay C. (1997). "Event studies in economics and finance". Journal of Economic Literature; 35(1):13-39.

[103] MacRae, C. D. (1977). "A political model of the business cycle", Journal of Political Economy, Vol. 85, No. 2. $239-263$.

[104] Malkiel, B. (1995). "Returns from Investing in Equity Mutual Funds 1971 to 1991,"Journal of Finance, Vol. 50, Issue 2. 549-572.

[105] Maloney, Michael T. and J. Harold Mulherin (2003), "The Complexity of Price Discovery in an Efficient Market: The Stock Market Reaction to the Challenger Crash", Journal of Corporate Finance, Vol. 9, Issue 4, pp. 453-479.

[106] Manning, N., (1991). "The UK oil industry: Some inferences from the efficient market hypothesis". Scottish Journal of Political Economy 38: 324-334.

[107] Mansfield, E D \& Pollins, B 2003, 'Economic interdependence and international conflict: New perspectives on enduring debate', Ann Arbor, MI: University of Michigan Press.

[108] Martínez, Juan/Santiso, Javier (2003): Financial Markets and Politics: The Confidence Game in Latin American Emerging Economies, in: International Political Science Review. 24 (3): 363-95.

[109] Mei, J. \& Guo, L. (2002), "Partisan Politics and Stock Market Performance: The Effect of Expected Government Partisanship on Stock Returns in the 2002 German Federal Election". Working paper

[110] Morck R, Yeung B. Internalization: an event study test. J Int Econ 1992;33(1-2):41-56 August

[111] Moser, C. and Rose, A.K. 2011. "Who Benefits from Regional Trade Agreement: The view from the Stock Market", National Bureau of Economic Research: Working Paper No. 17415.

[112] Mukhopadhyay, D. and Sarkar, N. (2003). "Stock Return and Macroeconomic Fundamentals in Model - Specification Framework: Evidence from Indian Stock Market. Indian Statistical Institute, Economic Research Unit". Discussion Paper. 1-28

[113] Myers, John and Bakay, Archie (1948) "Influence of Stock Split-Ups on Market Price," Harvard Business Review, Vol. 26. 251-55.

[114] Nguyen, A.P., Enomoto,C., (2009). "Acts of Terrorism and Their Impacts on Stock Index Returns and Volatility: The Cases of the Karachi and Tehran Stock Exchanges". International Business \& Economics Research Journal - Volume 8, Number 12.

[115] Nicholas Chen (2004). "Effect of the U.S. Presidential Election on Stock Market Performance", NUS Student investment society.

[116] Niederhoffer V., (1971). "The analysis of world events and stock prices", Journal of Business, 44(2), 193-219.

[117] Niederhoffer, V. 1971. "The Analysis of World Events and Stock Prices", The Journal of Business, Vol. 44, No. 2, pp. 193-219.

[118] Niederhoffer, V., Gibbs, S., \& Bullock, J. (1970). "Presidential elections and the stock market". Financial Analysts Journal, 26, 111-113.

[119] Nordhaus, W. D. (1975). "The political business cycle”, The Review of Economic Studies, Vol. 42, No. 2.169-190.

[120] Ortega, D. F., \& Tornero, Á. P. (2009). "Politics and Elections at the Spanish Stock Exchange". Paper presented at the 9th Global Conference on Business \& Economics, Cambridge University, UK.

[121] Pantzalis, C. Stangeland, D. A. and Turtle, H. J. (2000). "Political elections and the resolution of uncertainty: The international evidence", Journal of Banking \& Finance, Vol. 24, No. 10. 1575-1604.

[122] Peel, D. \& Pope, P. (1983). "General Election in the U.K. in the Post-1950 Period and the Behaviour of the Stock Market", Investment Analysis 67, 4-10

[123] Person, J. (2012). "Mastering the Stock Market: High Probability Market Timing and Stock Selection Tools". New Jersey: John Wiley \& Sons.

[124] Rafaqet Ali and Muhammad Afzal (2012). "Impact of global financial crisis on stock markets: Evidence from Pakistan and India". Journal of Business Management and Economics Vol. 3(7). 275-282.

[125] Ray M. Valadez, Marshall D. Nickles (2009). "The U.S. Presidency and the Stock market: A political relationship study of market relationship, Economic Journal Research in Business and Economic Journal

[126] Rigobon, R \& Sack, B (2005). 'The effects of war risk on US financial markets', Journal of Banking and Finance, Vol. 29, No. 7, pp1769-1789.

[127] Rigobon, R., and B.P. Sack. (2004) “The Impact of Monetary Policy on Asset Prices,” Journal of Monetary Economics, 51, 155375.

[128] Robin Jonsson and Jessica Radeschnig (2014). "From Market E ciency To Event Study Methodology: An Event Study of Earnings Surprises on Nasdaq OMX Stockholm", Bachelor Thesis in Economics submitted to Division of Business and Social Sciences. Malardalen University Sweden.

[129] Rosenstein, J., and S. Wyatt, “Outside Directors, Board Independence and Shareholder Wealth," Journal of Financial Economics 26, 1990, pp. 175-192.

[130] Sabnavis (2005). "How sensitive is the Stock Market". Business Standard, August 22.

[131] Sadorsky, P. (1999), “Oil price shocks and stock market activity”, Energy Economics, No. 2. 449469. 
[132] Salameh, H. \& AlBahsh, R. (2011), "Testing the Efficient Market Hypothesis at the Semi Strong Level in Palestine Stock Exchange - Event Study of the Mandatory Disclosure". International Research Journal of Finance and Economics Issue 69 (2011).

[133] Santa-Clara P, Valkanov R (2003). "The presidential puzzle: political cycles and the stock market". Journal of Finance. LVIII (5):1841-1872

[134] Sathyanarayana, Pushpa B. V. (2016). "Global stock markets reaction to special events: evidence from Brexit referendum". International Journal of Business and Administration research review. Vol. 1, Issue No. 4.

[135] Schwert G. W., (1989), "Why does stock volatility change over time?" Journal of Finance, 44 (5), $1115-53$.

[136] Schwert G. W., (1990), "Stock returns and real activity: A century of evidence", Journal of Finance, 45 (4), $1237-57$.

[137] Seppi, D. (1992). "Block Trading and Information Revelation around Quarterly Earnings Announcements," Review of Financial Studies, Vol. 5. 281-306.

[138] Shelor, R. M., Anderson, D. C., and Cross, M. L. (1990). "The impact of California earthquake on real estate firms stock value". The Journal of Real Estate Research, 5 (3), 335-340.

[139] Singh, Anoop (2006), "Macroeconomic volatility: The policy lessons from Latin America", IMF Working Paper WP/O6/166, International Monetary Fund, Washington, D.C. July.

[140] Stovall RH (1992). "Forecasting stock market performance via the presidential cycle". Financial Analysts Journal 48(3), 5-8.

[141] Sturm, R. R. (2013). "Economic policy and the presidential election cycle in stock returns", Journal of Economics and Finance April 2013, Volume 37, Issue 2. 200-215

[142] Subramani M, Walden E. (2001) "The impact of E-commerce announcements on the market value of firms", Information System Research, Vol. 12 (2):135-54.

[143] Suleman, M. T. (2012). Stock market reaction to good and bad political news. Asian Journal of Finance \& Accounting, 4(1), 299312

[144] Thomas, Susan, and Shah, Ajay (2002). "Stock Market Response to Union Budget". Economic and Political Weekly, February, 455458

[145] Tzachi Zach (2003). "Political Events and the Stock Market: Evidence from Israel”, International journal of business, 8(3).

[146] Vuchelen, J. (2003). Electoral systems and the effects of political events on the stock market: The Belgian case. Economics \& Politics, 15(1), 85-102.

[147] Wing-Keung Wong and Michael McAleer (2007). "Mapping the Presidential Election Cycle in US Stock Markets". Department of Economics Journal Articles, Vol 79 (11). 3267-3277.

[148] Zach, T. (2003). "Political Events and the Stock Market: Evidence from Israel". International Journal of Business, 8(3).

[149] Zhao X, Liano K, Hardin WG III (2004). "Presidential election cycles and the turn-of-the-month effect". Social Science Q 85(4):958-973

[150] Zuwena Zainabu (2014). "An assessment of the effect of general elections on the stock market returns in Kenya", a research project submitted to the University of Nairobi. 